\title{
Morocco: 2011 Article IV Consultation-Staff Report; Public Information Notice on the Executive Board Discussion; and Statement by the Executive Director for Morocco
}

Under Article IV of the IMF's Articles of Agreement, the IMF holds bilateral discussions with members, usually every year. In the context of the 2011 Article IV consultation with Morocco, the following documents have been released and are included in this package:

- The staff report for the 2011 Article IV consultation, prepared by a staff team of the IMF, following discussions that ended on July 28, 2011, with the officials of Morocco on economic developments and policies. Based on information available at the time of these discussions, the staff report was completed on September 19, 2011. The views expressed in the staff report are those of the staff team and do not necessarily reflect the views of the Executive Board of the IMF.

- $\quad$ A Public Information Notice (PIN) summarizing the views of the Executive Board as expressed during its October 5, 2011 discussion of the staff report that concluded the Article IV consultation.

- $\quad$ A statement by the Executive Director for Morocco.

The document listed below has been or will be separately released.

\section{Selected Issues Paper}

The policy of publication of staff reports and other documents allows for the deletion of market-sensitive information.

\author{
Copies of this report are available to the public from \\ International Monetary Fund • Publication Services \\ $70019^{\text {th }}$ Street, N.W. • Washington, D.C. 20431 \\ Telephone: (202) 623-7430 • Telefax: (202) 623-7201 \\ E-mail: publications@imf.org Internet: http://www.imf.org
}

\section{International Monetary Fund Washington, D.C.}




\section{INTERNATIONAL MONETARY FUND}

\section{MOROCCO}

\section{STAFF REPORT FOR THE 2011 ARTICLE IV CONSULTATION}

September 19, 2011

\section{KEY ISSUES}

Background: Several years of sound macroeconomic policies and political reforms left Morocco well-equipped to address the 2008 international crisis and to respond to pressing social demands. In this challenging environment, Morocco has performed well economically and has seen its social indicators improve.

Growth prospects: Despite the slow recovery in the Euro zone-Morocco's main trading partner-overall GDP is expected to grow between $4 \frac{1}{2}-5$ percent owing to good agricultural production and the strong performance of the nonagricultural sector, particularly services and domestic consumption. Unemployment is about 9 percent, but urban and youth unemployment remains high. The major medium-term challenge is to achieve high real GDP growth rates to reduce unemployment and improve living standards. Slow growth in Europe could affect economic activity and worsen prospects.

Resuming fiscal consolidation: Prudent policies in previous years provided a financial margin to deal with the international crisis and its aftermath. In 2011, the authorities addressed social demands by increasing public sector wages and keeping fuel and certain food prices stable through large subsidies. While there is fiscal space in the short run for spending to support the political reform process and ensure social cohesion, starting in 2012 Morocco would need to adopt significant fiscal measures, particularly reforming the generalized subsidies scheme, to ensure medium-term sustainability. While implementing the subsidy reform will be politically difficult, the government is committed to improving the targeting of subsidies, reducing their cost to 3 percent of GDP, and reducing public wages to 10 percent of GDP over the medium term.

Continuing financial sector development: The financial sector has reached a significant size, but further domestic resource mobilization is needed to support credit growth. With the budget financed domestically, there may be some risk of crowding out. The authorities have taken significant measures to encourage higher financial intermediation, savings, and new financial products. The funding of Moroccan banks, which includes funding for foreign subsidiaries, mainly relies on Moroccan deposits in Dirhams, which would help to mitigate risks associated with tighter liquidity in the Euro money market.

Improving productivity: Deepening structural reforms is essential to sustaining Morocco's productivity. The government has launched reforms to improve the business environment and social indicators to boost potential growth while reducing unemployment. 
Approved By Ratna Sahay and Thomas Dorsey
Discussions took place in Rabat from July 7-July 18, 2011. The staff team comprised Ms. Alonso-Gamo (head), Ms. Sab, and Messrs. Furceri, Gijon, Veyrune (all MCD), and Ms. Funke (FAD).

\section{CONTENTS}

INTRODUCTION

MEDIUM-TERM OUTLOOK

A. Maintaining Fiscal Sustainability in the Context of Social and Political Challenges

B. Monetary Policy Framework in Transition

C. Mobilizing Resources and Enhancing Asset and Liability Management-Banks' Challenges in a

Post-Excess-Liquidity Scene 10

D. Social and Structural Reforms 11

STAFF APPRAISAL

\section{TABLES}

1. Selected Economic Indicators, 2009-16 27

2. Central Government Finance, 2009-16 29

3. Central Government Finance (percent of GDP), 2009-16 30

4. Balance of Payments, 2009-16 31

5. Monetary Survey, 2006-12 32

6. Financial Soundness Indicators of the Banking Sector, 2005-March 2011 33

7. Selected Social Indicators, 2000-09 34

8. External Debt Sustainability Framework, 2006-16 35

9. Public Sector Debt Sustainability Framework, 2006-16 36

\section{FIGURES}

1. Real and External Developments 20

2. Fiscal and Financial Market Developments 21

3. Monetary and Financial Sector Developments 22

4. Autonomous Factors, Systemic Liquidity, and Reference 23 
5. Real Effective Exchange Rate Indices and Competitiveness 24

6. Cross-Country Comparisions: Social Indicators 25

7. External Debt Sustainability: Bound Tests 26

8. Public Debt Sustainability Bound Tests

\section{BOXES}

1. Could Investment be More Growth-Enhancing? 14

2. The Contribution of the OCP to the Moroccan Economy 15

3. Downside Risk Fiscal Scenario: Key Macroeconomic Indicators 16

4. Banks' Asset-Liabilities Management and Resource Mobilization Challenges 17

5. FDI Attractiveness and Business Climate 18

6. Subsidies 19

\section{ANNEX}

I. Transition of Fiscal Presentation to GFS2001 37 


\section{INTRODUCTION}

1. Morocco has successfully met major challenges following the global crisis.

Thanks to several years of sound macroeconomic policies and political reforms, Morocco was well equipped to address the 2008 international crisis and to respond to the social demands that have emerged during the Arab Spring. In this challenging environment, Morocco has performed well economically and has seen its social indicators improve.

2. While the medium-term economic outlook remains generally favorable, the major challenge for Morocco remains that of achieving a GDP growth rate that will help reduce unemployment and improve living standards, while ensuring mediumterm fiscal sustainability. Since early 2011 , declining growth among Morocco's main trading partners and rising commodity prices have complicated policymaking. Although in 2011 the Moroccan government has begun implementing short-term policies to address social constraints, in 2012 the government intends to start reorienting and reducing public expenditure to achieve fiscal sustainability while fostering inclusive and sustainable growth in the medium term. (Box 1).

\section{RECENT DEVELOPMENTS AND OUTLOOK}

\section{In response to social demands, the} Moroccan government is pursuing significant constitutional and political reforms, and has increased spending during 2011 on subsidies, wages, and pensions. The aim is for the political system to shift toward a constitutional monarchy, create the institutional framework for expanding voice and participation in the political process, promote social, gender, and regional equality, and increase transparency and accountability. A referendum on July 1, 2011, overwhelmingly supported these reforms. The government is planning additional legislation to underpin new constitutional provisions, including measures to ensure fiscal sustainability, andin consultation with the private sectorimprove the business climate. Such policies are expected to support living standards while enhancing potential growth. Parliamentary elections have been called for November 2011.

\section{Morocco's recent economic} performance has been favorable overall:

- Strong performance by nonagricultural GDP: Nonagricultural GDP grew by 4.5 percent in 2010 compared to about 1 percent in 2009, reflecting the recovery in certain Euro zone countries, Morocco's main trading partners, as well as the higher demand of its phosphate products from non-EU countries. However, because of a contraction in agricultural output, which represents 13-17 percent of GDP, overall real GDP grew by only 3.7 percent in 2010 . GDP growth performance is expected to be much stronger in 2011, at about 41/25 percent, one of the highest in the region, reflecting sustained growth in the nonagricultural sector, particularly services-including the tourism sectorand domestic private and public 
consumption, and a rebound in agricultural output (Table 1, Figure 1). The authorities project GDP growth at 4.8 percent in 2011.

- Inflation remains low and under control. In 2010, period average inflation remained at 1 percent. In 2011, a fall in domestic food prices-resulting from the higher local supply of food-as well as the existing subsidies, which prevented inflationary pressures stemming from higher international prices and secondround effects resulting from public wage increases, are expected to help limit the increase in the average inflation to around 11/2 percent (Table 1 ).

- The sharp increase in expenditures is deteriorating the budget deficit. The budget deficit may reach $51 / 2-6$ percent of GDP due to an increase in expenditures amounting to 3 percent of GDP relative to the 2011 budget, largely resulting from the upturn in outlays to compensate for prices of petroleum products and certain foodstuffs (Tables 2-3, Figure 2, Box 6), despite strong offsetting measures to control other areas of spending.

- A terms-of-trade shock has caused a slight deterioration in the external balance. The current account deficit may increase to about 5 percent of GDP at end-2011. Although Moroccan exports, including phosphate and its derivatives, have performed well, and transfers from Moroccans living abroad and tourism receipts-despite the terroristic attack in Marrakesh on April 28-have grown, this may not completely offset the increase in imports caused by rising international food and oil prices. In addition, the effects of the terms of-trade shock have been exacerbated by keeping fuel and certain food prices stable through large subsidies, which has suppressed substitution effects in consumption decisions. Gross international reserves are expected to decline slightly at end-2011, while remaining comfortable, at above 5 months of imports of goods and services (Table 4).

- Growth in credit continued against a backdrop of declining liquidity. Credit to the economy grew by 7.4 percent in 2010 , after 10.9 percent in 2009. During the first five months of 2011, growth in credit slowed down and deposits decreased slightly, while banks' resources were supported by the mobilization of deposit certificates. Systemic liquidity contracted as a result of a decrease in foreign assets and a larger-than-usual increase in currency in circulation during the first five months of 2011. The staff expects credit to increase by 6.2 percent in 2011; while the authorities project credit growth at 8 percent for the year (Table 5, Figure 3).

- Near-term downside risks to the economic outlook are related to the economic performance of European partners, the development of food and fuel prices, and regional political developments. Spillovers from sluggish growth in European partners and/or further regional instability could affect economic activity and the balance of payments (BOP) through lower tourism receipts, foreign direct investment (FDI), and trade. The ongoing political reforms, including the recent changes to the constitution and forthcoming elections, should help mitigate political risks. The government could also undertake further social spending measures beyond those 
already under way, which might further adversely affect public finances, debt

dynamics, and liquidity. On the upside,
Morocco would benefit from higher phosphate prices (Box 2).

\section{MEDIUM-TERM OUTLOOK}

5. The world economic recovery in $\mathbf{2 0 1 0}$ to some extent supported growth in Morocco; yet new risks emerged in 2011. The slowdown in growth in a number of countries in the Euro zone, Morocco's main trading partner, could affect economic activity and worsen medium-term prospects Furthermore, persistently high commodity prices, the regional context, and global financial instability add uncertainties to the economic outlook.

\section{Morocco is expected to continue} recording a strong economic performance. Despite increasing productivity, growth is expected to remain at about $4 \frac{1}{2}-5$ percent in 2012 due to the impact of fiscal consolidation on domestic demand. Over the medium term, growth could reach 6 percent. This will hinge on continued macroeconomic stability and the implementation of planned structural reforms. For this purpose, the authorities intend to bring the medium-term budget deficit down to around 3 percent of GDP, which should bring public debt to about 50 percent of GDP over the medium term. This should slow down the pace of imports, in particular of energy products and of consumer goods, which could help reduce the current account deficit to about $2 \frac{1}{2} 2$ percent of GDP and external debt to below 23 percent of GDP in 2016.

\section{POLICY DISCUSSIONS}

\section{A. Maintaining Fiscal Sustainability in the Context of Social and Political}

\section{Challenges}

\section{During the fiscal year 2011 and} following domestic unrest, the authorities have increased public spending in some areas. Maintaining prices for certain food products and fuel unchanged in the context of rising international commodity prices, will require spending on food and fuel subsidies of about $5 \frac{1}{2}$ percent of GDP in 2011, considerably in excess of the 2.1 percent of GDP estimated in the 2011 budget. In addition, all civil service wages were increased by a nominal amount of about US\$75, which is expected to increase the wage bill by 0.2 percent of GDP to 10.7 percent of GDP in 2011. The wage increase had been partially anticipated in the 2011 budget, which explains the limited additional impact from this measure on the 2011 outcome. Other policy measures, including the acceleration of promotions for civil servants, and an increase in the minimum wage, are not expected to affect the fiscal outcome for 2011. The general increase in the minimum pension will affect the mandatory pension schemes, which might in turn require some not-yet-quantified transfers from the government in the coming years. Overall, these measures are projected to 
increase spending by $2 \frac{1}{2}$ percent of GDP compared to the 2011 budget.

\section{At the same time, the authorities} took significant offsetting measures, which will help to contain the budget deficit at around 5.7 percent of GDP. Revenue efforts were intensified and better-than-budgeted revenue collections in the first half of 2011mainly from indirect taxes-are expected to continue in the second half. This is expected to result in an improvement in revenues of 1 percent of GDP compared to the 2011 budget. Despite the implementation of the third phase of the income tax reform, including an increase in the tax threshold, tax brackets, and reduced rates, stronger revenue collection efforts are now expected to leave total revenues almost unchanged compared to 2010 at 25 percent of GDP. On the expenditure side, all budget entities have been requested to economize 10 percent of budgeted allocations for several nonessential current spending items. In addition, budgeted transfers to several public entities with treasury surpluses will be reduced without affecting their spending capacity. These two measures are expected to produce savings of just above 1 percent of GDP compared to the 2011 budget. The cost of the elections scheduled in November will be absorbed in the existing budget envelope. Staff underlined that there will be no room for any additional spending increases for 2011. Overall, counterbalancing measures on the revenue and expenditure side would amount to 2 percent of GDP, which limits the expected deterioration of the fiscal balance to $1 \frac{1}{2}$ percent of GDP compared to the 2011 budget.

\section{The authorities agreed that after containing fiscal expansion in 2011, a firm}

consolidation plan is required for 2012 and the medium term to ensure fiscal sustainability. Fiscal consolidation-reducing the budget deficit to maintain public debt at sustainable levels-should come from a combination of increased revenues and expenditure containment. In line with Article 77 of the new constitution and the draft organic budget law, which lay down the principle of safeguarding fiscal stability, the authorities intend to bring the deficit back to about 3 percent of GDP in the medium term. This would be in line with a debt-to-GDP ratio converging to a level of about 50 percent (Table 9). In the absence of corrective measures, the budget deficit may reach $61 / 2-$ $71 / 2$ percent of GDP and consequently public debt will continue to rise (see Box 3 ).

\section{To achieve this fiscal adjustment, the authorities intend to resume and accelerate the implementation of the following reforms:}

- Raise revenue. The authorities intend to intensify their revenue collection efforts by:

(i) broadening the tax base; and

(ii) improving revenue administration. Nontax revenues would also be expected to improve as publicly owned enterprises benefit from the economic recovery and augment their contribution to the budget. The mission suggested that the authorities should redesign the envisaged VAT reform - reducing the number of VAT rates from four to two-to maintain the current revenue level or to increase revenues. These and other reforms would allow maintaining or even improving upon the current revenue levels despite losses in customs revenues from continued trade liberalization. 
- Contain expenditure. Civil service reform would improve expenditure efficiency and would also help bring the wage bill back to below 10 percent of GDP, as aimed for by the authorities. Furthermore, a reform of fuel subsidies-replacing universal subsidies with targeted transfer programs-is envisaged. Such a reform could significantly reduce the burden to the budget and eliminate the vulnerability of public finances with respect to world market developments while rationalizing consumption. The authorities emphasized that subsidy reform will be politically difficult. The mission underlined that to be successful a subsidy reform would need to overcome public and political resistance through good targeting and a welldesigned and well-implemented communication strategy. Given that reforms take time, a price mechanism allowing for some gradual adjustment in prices could be introduced as a transition to a more comprehensive reform.

- Enhance expenditure efficiency. The authorities also intend to improve the efficiency of public investment by enhancing the project selection process and by giving more room to private investment, including investment in infrastructure. This, together with subsidy reforms would allow for social spending that would include universal health services and education. ${ }^{1}$ The mission pointed out that private sector participation in public investment-for example in the context of public private partnerships (PPPs)—requires a solid

\footnotetext{
${ }^{1}$ Descriptive statistics for social indicators are reported in Figure 6 and Table 7.
}

institutional and legal framework to adequately manage fiscal risks from such arrangements. The authorities intend to design and implement a framework based on first experiences with forthcoming projects. Given the lack of experience with PPPs in the public administration, this approach could be risky if initial projects have sizable fiscal implications, such as might arise from contingent liabilities.

- Ensure the sustainability of the compulsory public pension system. According to the latest actuarial projections, compulsory public pension plans will soon have to rely on their capital base to finance pension payments. The Caisse Marocaine des Retraites, which manages pensions for civil servants and military personal, will start depleting its reserves from 2014 on. The other two major compulsory pension schemes will have more time but would eventually reach a situation where pension payments exceed contributions.

A technical commission has proposed a two step reform. First, a parametric reform, including the gradual increase of the retirement age and contributions to the pension system, together with a revision of the base salary used to calculate the pension, would give the pension funds some more years of financial sustainability. Second, a comprehensive reform aiming at enlarging the coverage of the pension scheme $^{2}$ and the introduction of a multipillar system, including a basic pension under a pay-as-you-go scheme, a compulsory scheme, and a fully funded optional scheme. ${ }^{2}$ Staff stressed that apart

\footnotetext{
${ }^{2}$ According to the ILO, only 26 percent of the active population is currently covered by the pension system.
} 
from the basic pension, all pension

schemes should be designed to be fully funded to ensure financial sustainability in the future.

\section{B. Monetary Policy Framework in Transition}

11. Monetary policy has kept inflation in line with the objectives set by Bank AlMaghrib (BAM). BAM assesses inflation risks based on a multiple-criterion approach and aims at influencing the overnight interest rate (operational target) to address inflationary risks while maintaining a fixed exchange rate and partial capital controls. Core inflation remained below 2 percent since early 2009, and rising international prices for certain commodities did not pass through, which also contributed to keep headline inflation low.

\section{BAM's efficient liquidity} management helped to keep the overnight interest rate close to its benchmark interest rate. BAM targeted banks' liquidity needs accurately enough to keep the overnight rate close to its benchmark interest rate, which has been set at 3.25 percent since March 2009. Facing a significant decline in systemic liquidity due to a decrease in official reserves, BAM lowered the reserve requirement from $16 \frac{1}{2} 2$ to 6 percent in five steps and withdrew passbook savings accounts from the reserve base on April 21, 2011 to ease the pressures on the interbank market. However, BAM also had to increase its refinancing to banks up to 5 percent of their deposits at end-July 2011, as the structural liquidity position of the banks reached a low point. Staff considers that there is now limited room for reducing the reserve requirement further as the authorities should make sure that the banks maintain a sufficient level of reserve at the central bank to address liquidity risks in the current context of tightening liquidity.
13. The authorities are envisaging an eventual move to a more formal inflation targeting system in conjunction with a more flexible exchange rate. Staff considers that BAM has the necessary independence, expertise, technical resources, range of instruments, and level of foreign reserves to introduce an inflation-targeting framework and a flexible exchange rate. Bank supervision for risk management is effective and foreign currency exposure is at a low level. Staff is of the view that a more flexible exchange rate regime would reduce the need for frequent changes in the reserve requirement and would remove the constraint of offsetting capital flows which may occur subsequent to changes in the interest rate policy in a fixed exchange rate arrangement. However, the authorities emphasized, and staff concurs, that the timing should be carefully considered, since the transition to a flexible exchange rate requires measures to ensure fiscal sustainability, particularly reforming the universal subsidy scheme, and to prevent an adverse impact on financial stability. In the short term, the foreign exchange market could be further developed by broadening the central bank spread from 0.6 percent to at least 2 percent (the IMF standard for conventional peg regimes) to encourage the development of interbank foreign exchange transactions.

\section{A more flexible exchange rate would} also enhance competitiveness. Fund staff analysis of Morocco's real exchange rate, based on the three CGER methodologies, finds that the deviation from the equilibrium rate varies widely among the three methodologies 
used, from a range of -8 percent to

23 percent. As a result, results should be interpreted with caution. However-and despite the fact that the real effective exchange rate depreciated by about 4 percent in 2010 - staff believes that trends in the current account balance since 2007 could point to eroding external competitiveness in the Moroccan economy (Figure 5). Staff considers that improving competitiveness, through bold structural reforms and an eventual move to a more flexible exchange rate regime, remains an important priority.

\section{Mobilizing Resources and Enhancing Asset and Liability Management- Banks' Challenges in a Post-Excess-Liquidity Scene}

15. Morocco's financial sector has made considerable headway, but it would need to mobilize additional resources to support financial development and adequate credit growth. The banking sector is important, exceeding 110 percent of GDP, supported by the deposits of Moroccans living abroad and the establishment of banking networks in Africa by Moroccan banks. The Casablanca stock exchange is one of the most capitalized and diversified, in terms of sectors, in Africa. The authorities issued the statute "Casablanca Finance City" in December 2010 and nominated the "Moroccan Financial Board" to pilot the promotion of Casablanca as an international (and regional) financial center. The authorities have taken steps to promote access to banking and savings services to support banks' deposit mobilization, which has slowed down, and to develop markets to facilitate the asset and liability management of banks, whose resource utilization exceeds 100 percent on average (Box 4). Moroccan banks' funding, including funding for foreign subsidiaries, relies mainly on Moroccan deposits in Dirhams, while wholesale foreign currency funding and external rollover needs are limited, reducing the risk related to difficulties in the Euro money market.

\section{The policy of strengthening core} capital has been generally successful but efforts to further increase the capital of certain institutions should continue. The capital adequacy ratio of the system had risen to 12.3 percent at end-2010, up from 11.8 percent in 2009 , and NPLs steadily declined from 6.1 percent of total loans in 2008 to 4.8 percent in 2010 (Table 6). However, credit quality appears to have slipped since 2009, as indicated by the increase in the cost of risk in 2009-2010 and a slight increase in the NPL ratio during the first five months of 2011. Efforts to strengthen core capital will continue, in particular for those institutions that have failed to reach the threshold of 9 percent of exposures as targeted by BAM. Although banks' solvency appears strong by international standards, staff considers that BAM should continue encouraging banks to reinforce their core capital (common equity and reserves) because of risks related to their relatively high "large exposures ratio to Tiers 1" (Table 6) and to Moroccan banks' subsidiaries abroad. 


\section{Social and Structural Reforms}

17. The authorities are continuing their efforts to implement an ambitious program of structural reforms to enhance productivity. The favorable economic performance recorded over the past decade is largely attributed to reforms in key economic sectors (such as the financial sector and public enterprises) and to efforts to improve the business climate, which needs to be strengthened further. In this context, the authorities have set a committee to enhance the business environment's ability to continuously attract FDI (Box 5).

\section{Unemployment has decreased} considerably in recent years, but it remains high, especially among the youth.

Unemployment fell from 13.4 percent in 2000 to 9.1 percent in 2009 (Table 7) but this trend came to a halt in 2009 due to the global crisis. Unemployment remains an urban phenomenon. The average education level of the unemployed is higher than that for the total labor force, signaling the difficulties for people with secondary and higher education in finding jobs. In addition, unemployment among the youth remains particularly high and has proven more difficult to tackle. In this context, reforms designed to enhance labor market flexibility are essential. The reform of the Labor Code in 2004 has brought more flexibility to the labor market and better regulation, especially in the hours of work, the right to strike, and in syndicated representation and collective bargaining. However, further reforms aimed at reducing minimum wages and hiring costs are critical to reduce youth unemployment (Selected Issues Paper on Unemployment).

\section{Despite important gains in living} standards, social challenges remain. The authorities have continued to support social policies which have helped lower the poverty rate by $7 \frac{1}{2} 2$ percent between 1994 and 2008, while improving social indicators (Table 7). Still, segments of the population remain socially and economically disadvantaged. Health indicators-especially for women and children-are below the norm, with high incidence of mortality. Literacy rates remain low relative to other countries with similar income levels. In addition, although access to primary education is universal, only two-thirds of children aged 6-11 complete primary school. The National Human Development Initiative for 2011-15, the recent extension of medical coverage to include disadvantaged populations, and the regionalization process are designed to tackle these issues.

20. Morocco may also benefit politically and economically in the medium term from the "advanced status" it secured with the EU which could lead to freer access to the European labor market and enhance FDI attractiveness. However, trade liberalization under the EU-Mediterranean Association Agreements needs to be strengthened as it remains incomplete, with many barriers still hampering market access, particularly in the agricultural and service sectors. 


\section{STAFF APPRAISAL}

21. Morocco has recorded a strong economic performance but important challenges remain ahead. Morocco has enjoyed sustained growth over the last decade owing to prudent macroeconomic policies and the implementation of structural reforms. This performance helped achieve a solid fiscal position while reducing public debt. However, productivity and the business climate need further improvement to enhance the role of the private sector in promoting long-term sustainable growth. Unemployment remains high, especially among the youth, stressing the need to accelerate structural reforms.

\section{Containing public expenditure,} particularly by reforming the generalized subsidies system, will be key to ensuring medium-term fiscal sustainability. The increase of subsidies and public wages to respond to social demands will adversely affect the medium-term fiscal position. The deterioration of the fiscal position will be largely due to the current subsidy system, which is expensive, highly inefficient and inequitable as it fails to provide an efficient support to the least favored segments of the population. A well-targeted subsidy system will be less costly and would better support the poor. Given that upward pressures on expenditure will likely continue, with higher commodity prices and growing social demands, a reorientation of spending is essential to ensure medium-term fiscal sustainability. Wage increases should be in line with productivity, and universal subsidies should be replaced by targeted transfers, which would allow for more effective social spending, providing more room for social protection and health and education spending.
While these reforms may be politically difficult, staff strongly encourages the authorities to pursue their efforts to implement the intended reforms, including in the event of delays some gradual price adjustment mechanism as a transition to a more comprehensive reform. In addition, the authorities should continue to intensify their revenue collection efforts by broadening the tax base and improving tax administration. Additional revenue efforts could help achieve more ambitious consolidation path reducing the debt level to below 50 percent of GDP or if necessary compensate for slower than expected implementation of expenditure reforms. In this respect, the planned VAT reform should be designed to ensure stable-or even higherrevenues.

23. The authorities should improve the efficiency and the quality of expenditure to allow for sufficient, well-targeted social spending. In order to achieve medium-term sustainability, the authorities aim to improve the efficiency in public investment projects by developing better procedures for the selection of projects and allowing a greater participation of the private sector. Moreover, the authorities are also contemplating a reform of the public pension system to ensure its long-term financial sustainability. Staff considers that these measures would help reorient expenditures toward key priority areas, such as education and health.

\section{An eventual move to a flexible} exchange rate would strengthen the BAM monetary policy framework. Staff is also of the view that a flexible exchange rate would support a more active interest rate policy in line with the BAM monetary policy framework. 
A more flexible exchange rate would also enhance competitiveness. Staff concurs with the authorities that the timing should be carefully considered and coordinated with other macroeconomic policies and necessary preparatory measures, so as to preserve medium-term fiscal sustainability and financial stability-which underscores the need to proceed promptly with those supporting policies.

\section{The financial sector has been} growing considerably, but further development will hinge on the ability to mobilize domestic savings. Given lower external flows and higher government financing requirements, financial development and appropriate credit growth will require effective domestic resource mobilization. Staff supports the authorities' efforts to improve financial intermediation and secure the mobilization of a greater share of savings to provide additional resources to the financial sector. In the context of tighter liquidity, the authorities should be careful that domestic financing of the government deficit does not crowd out and further reduce credit to the private sector. Moreover, the authorities could further encourage banks to reinforce their core capital to make them more resilient to shocks.

\section{Accelerating structural reforms is necessary to boost potential growth and} social indicators. Morocco has made important progress in improving governance and attracting foreign direct investments. However, additional efforts are required to strengthen governance, the business climate, and trade integration with European partners, in order to continue to attract FDI and increase human capital. In this regard, staff considers that the recent constitutional reform and the creation of the National Committee for the Business Environment should promote inclusive growth. Moreover, further reforms aimed at reducing minimum wages and hiring costs are critical to reducing youth unemployment.

27. It is proposed that the next Article IV consultation be held on the standard 12-month cycle. 
Box 1. Could Investment be More Growth-Enhancing?

Although investment rates to GDP have increased significantly over the last decade in Morocco, this has not translated into higher economic growth. While during 1999-2010 Morocco's investment rate was the second largest in the sample below, its growth rate is relatively lower. ${ }^{1}$ The quality and efficiency of investment projects may contribute to explain these differences.

Although the efficiency of investment, measured by the ICOR, ${ }^{2}$ for Morocco has declined during 2005-10, it remains high relative to the sample below, suggesting inefficiencies in the production process. While the ICOR analysis above is useful to highlight economic inefficiencies that hamper actual growth performance, it says little about Morocco's growth potential. In particular, modern growth theory emphasizes the "advantage of backwardness." ${ }^{3}$ In other words, the more distant a country is from the global technological frontier, the faster it is expected to grow, but only if it has institutions and policies that facilitate catching up with relevant technologies developed elsewhere. In this respect, Morocco has not made full use of this potential advantage as it still needs to further implement critical structural reforms. Economic openness, improvements in institutional quality, and strengthening of human capital are key for such technological adaptation or catching up to occur.

${ }^{1}$.All data for 2009, which were biasing the results due to the crisis, were excluded from the average.

${ }^{2}$.ICOR is the annual investment divided by the annual increase in GDP.

3. Aghion, Philippe and Peter Howitt, "Appropriate Growth Policy: A Unifying Framework" Journal of the European Economic Association 4 (April-May 2006): 269-314.

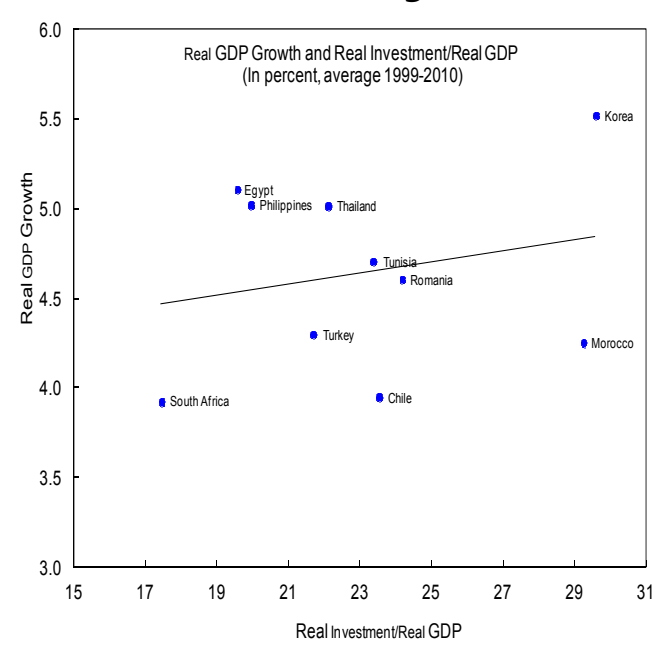

Sources: World Economic Outlook; and Fund staff calculations.

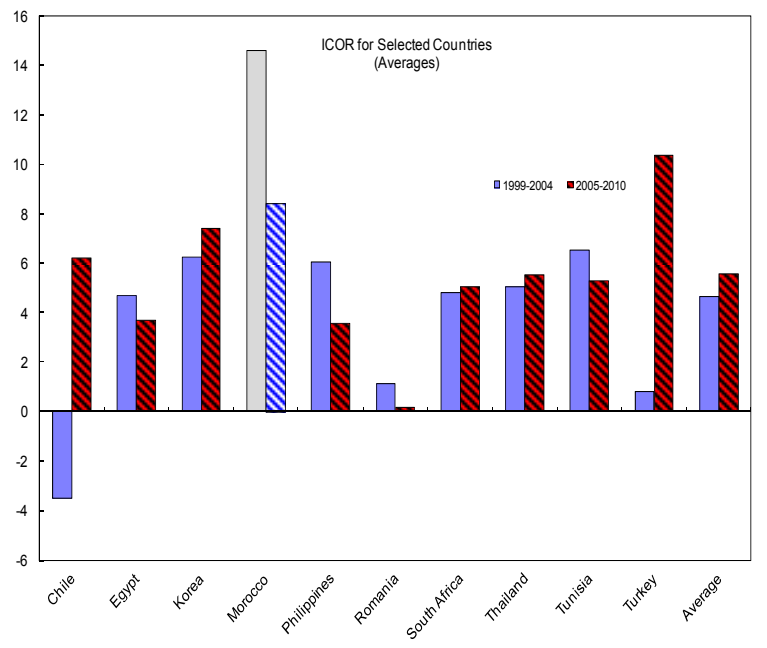




\section{Box 2. The Contribution of the OCP to the Moroccan Economy}

The Office Cherifien des Phosphates (OCP) Group is the largest Moroccan enterprise and its activities cover the entire phosphate value chain, from phosphate rock mining to chemical processing of phosphoric acid and fertilizers. With the world's largest phosphate reserves, mostly located in the Khouribga base in the center of Morocco, the OCP is the first exporter of rock phosphate and phosphoric acid in the world and one of the main exporters of phosphate-based fertilizers.
The phosphate sector is a key driver of the country's economy, employing more than 18,000 employees and representing, in value, approximately one quarter of Morocco's total exports and about 3.5 percent of GDP.

In recent years, the OCP has set up several processing joint ventures with plants located in Morocco and abroad with partners including Brazil, Belgium, Germany, India, and Pakistan. Over the medium term, the OCP plans to increase its rock production capacity to 50 million tons and its downstream fertilizer production through targeted strategic partnerships.

\section{Export shares (2009)}
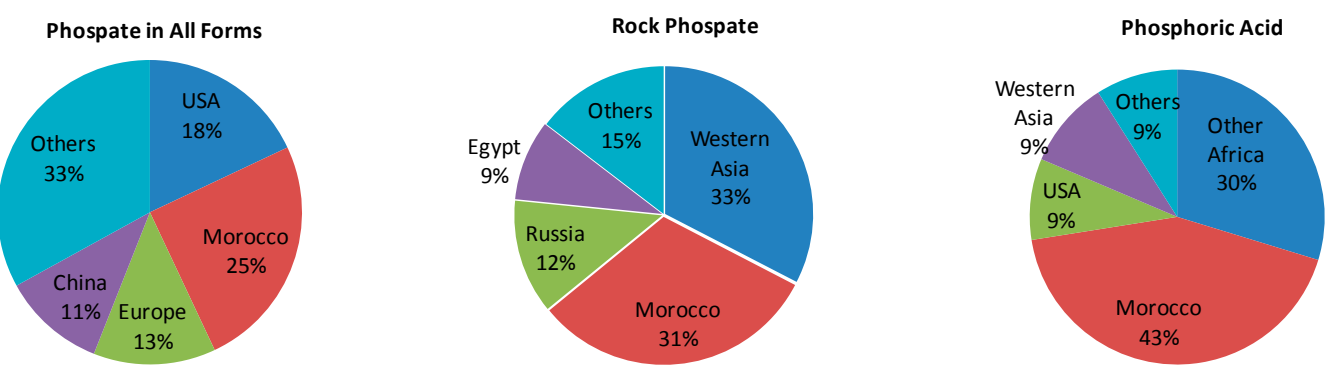


\section{Box 3. Downside Risk Fiscal Scenario: Key Macroeconomic Indicators}

The alternative scenario reflects the medium-term outlook for a case of no expenditure reforms and without additional revenue efforts. If the envisaged public spending reforms and revenue efforts were not implemented, fiscal consolidation would not be achieved and overall economic outcomes would be less favorable, specifically, growth and productivity would be more constrained in the medium term, and the current account would worsen.

Under the alternative scenario, fiscal sustainability would be at risk, as deficits could reach $71 / 2$ percent of GDP. If the size of the wage bill and spending on food and fuel subsidies are not addressed by the envisaged reforms, public expenditure would remain at about 32 percent of GDP.
Also, government revenues are expected to remain at current levels of about 25 percent of GDP if no efforts are undertaken to expand the revenue base. Under these circumstances, the fiscal deficit could reach between 6.5 and 7.3 percent of GDP in the medium term. Under this scenario, government debt would reach, by the end of the projection period, over 65 percent of GDP, which is considerably higher than the level of 50 percent of GDP, which could be generally considered advisable for an emerging market country.

\begin{tabular}{|c|c|c|c|c|c|c|}
\hline \multicolumn{7}{|c|}{ Key Macroeconomic Indicators: Baseline and Alternative Scenarios } \\
\hline & 2011 & 2012 & 2013 & 2014 & 2015 & 2016 \\
\hline & \multicolumn{6}{|c|}{ Baseline Scenario } \\
\hline Output growth (percent) & 4.6 & 4.6 & 4.9 & 5.2 & 5.5 & 5.9 \\
\hline Inflation (end of period, percent) & 2.0 & 2.7 & 2.6 & 2.6 & 2.6 & 2.6 \\
\hline Budget balance (percent of GDP) & -5.7 & -5.3 & -4.7 & -4.0 & -3.5 & -3.0 \\
\hline Revenue (percent of GDP) 1/ & 25.6 & 25.2 & 25.5 & 25.5 & 25.6 & 25.6 \\
\hline Expenditure (percent ofGDP) & 31.3 & 30.5 & 30.2 & 29.6 & 29.1 & 28.6 \\
\hline Total government debt (percent of GDP) & 54.2 & 55.5 & 56.0 & 55.8 & 54.9 & 53.5 \\
\hline Current account balance (percent of GDP) & -5.2 & -4.0 & -3.5 & -3.1 & -2.7 & -2.3 \\
\hline \multirow[t]{2}{*}{ Gross reserves (in billions of U.S. dollars) 2/ } & 23.4 & 23.6 & 23.9 & 24.8 & 26.3 & 28.6 \\
\hline & \multicolumn{6}{|c|}{ Alternative Scenario } \\
\hline Output growth (percent) & 4.6 & 4.6 & 5.0 & 5.0 & 5.0 & 5.0 \\
\hline Inflation (end of period, percent) & 2.0 & 2.5 & 2.5 & 2.5 & 2.5 & 2.5 \\
\hline Budget balance (percentof GDP) & -5.7 & -7.0 & -7.3 & -7.1 & -6.8 & -6.5 \\
\hline Revenue (percent of GDP) 1/ & 25.6 & 25.0 & 25.0 & 25.0 & 25.0 & 25.0 \\
\hline Expenditure (percent ofGDP) & 31.3 & 32.0 & 32.3 & 32.1 & 31.8 & 31.5 \\
\hline Total government debt (percent of GDP) & 54.2 & 57.1 & 60.1 & 62.8 & 65.0 & 66.7 \\
\hline Current account balance (percent of GDP) & -5.2 & -4.9 & -4.6 & -3.9 & -3.6 & -3.1 \\
\hline Gross reserves (in billions of U.S. dollars) 2/ & 23.4 & 22.8 & 21.7 & 21.3 & 21.5 & 22.5 \\
\hline \multicolumn{7}{|c|}{$\begin{array}{l}\text { Sources: Fund staff estimates. } \\
1 \text { Includes changes in the balance of other special treasury accounts. } \\
2 \text { / As of } 2009 \text {, reserves include the new SDR allocation. }\end{array}$} \\
\hline
\end{tabular}




\section{Box 4. Banks' Asset-Liabilities Management and Resource Mobilization Challenges}

After years of easily accessible resources due to abundant liquidity generated by a strong BOP and rapid credit growth, banks will have to adapt their resource mobilization and asset-liability management strategy to avoid having the current situation of tighter liquidity and higher deposit utilization constrain their activities.

\section{Enhanced resource mobilization}

- Fostering financial intermediation. Under the supervision of BAM, the postal bank, licensed in 2009, started rolling over its business plan progressively in 2010 to ensure that risks were adequately addressed. The creation of the postal bank was part of a World Bank DPL loan and its design draws on successful international experiences. The postal bank upgraded the services previously provided by the post office and now offers a larger range of deposit and payment services which are expected to attract new clients not yet targeted by commercial banks. Other measures were taken to encourage the recourse to banking services instead of cash for payments. Moreover, BAM signaled to commercial banks that they should not rely excessively on its refinancing facilities but should strengthen efforts to enlarge their deposit base. Overall, the authorities aim at reaching a ratio of access to financial services of 66 percent by end- 2013 .
- Increasing savings. The Ministry of Finance lifted the ceiling on savings accounts and introduced new savings products linked to the purchase of real estate and stocks and education financing to boost savings.

\section{Asset-liability management}

- Tapping market resources: The development of a market for certificates of deposit (CDs) would help banks to diversify their resources away from deposits. Larger depositors, such as companies, converted some time deposits into CDs, which have the advantage of stabilizing debt maturities for banks, as large depositors tended to withdraw their time deposits before maturity. BAM also included DCs among the eligible collateral for its refinancing operations, supporting the liquidity of the DC market and lengthening their maturities.

- $\quad$ Securitizing banks' assets: the authorities allowed banks to issue covered bonds to address banks' balance sheet maturity mismatches. Although any type of banks' claim is eligible for securitization, mortgage loans are typically those most likely to be securitized.

- Developing a yield curve: The Treasury started benchmarking certain maturities, and the BAM is publishing repo rates for different maturities to support the development a yield curve. 


\section{Box 5. FDI Attractiveness and Business Climate}

Before the global crisis, Morocco was attracting growing volumes of foreign direct investment (FDI)-from 2003-08, the annual average growth of FDI has been 5.1 percent, compared to about 3 percent over 1999-2002. The fact that FDI was growing until recently reflects the significant progress that Morocco has made in improving investment conditions, especially by enhancing the transparency and predictability of policies and regulations governing investment, as well as by reducing the time and cost of administrative procedures. Based on the OECD FDI regulatory restrictiveness index, the average level of Morocco's restrictions is comparable with the median of the OECD and non-OECD countries that adhere to the OECD Declaration on International Investment and Multinational Enterprises.

As indicated by the high negative correlation between the FDI regulatory restrictiveness index and the share of FDI to GDP, the relatively low level of restrictions in Morocco has played an important role in attracting FDI into the country. However, additional efforts to improve the business climate, especially for local entrepreneurs, would be needed to restore the pre-crisis growth rate of FDI. The Doing Business 2001 Report ranked Morocco 114th out of 183 economies in Ease of Doing Business.

In this context, by end-2009, the authorities created the National Committee for the Business Environment to implement reforms to the business climate, in partnership with the private sector. In 2010, the Committee's action plan included 12 priority activities intended to facilitate achievement of the following four objectives: (i) streamlining and strengthening transparency of administrative procedures, (ii) modernizing business law, (iii) improving the settlement of commercial disputes, and (iv) enhancing collaboration and communication related to reforms. The 2011 action plan includes two main priorities: (i) facilitating access to land, and (ii) in the context of the regionalization process, the harmonization and the regulation of the administrative procedures at the regional level. These reforms should facilitate greater economic diversification, create jobs, and lower unemployment.

FDI Restrictiveness Index 2010

( $\mathrm{o}=$ lesst restricted; $1=$ more restricted)
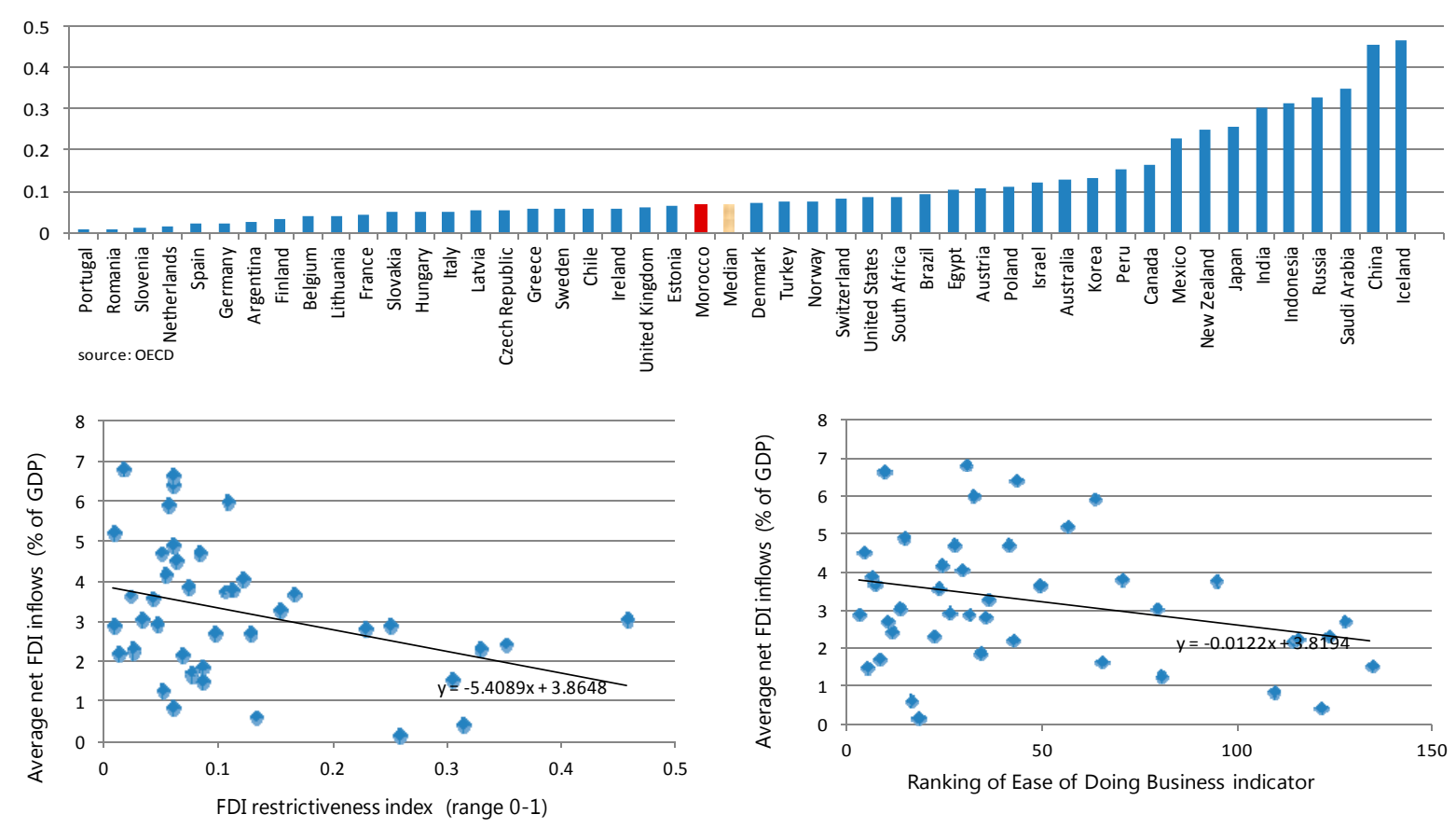


\section{Box 6. Subsidies}

Subsidies are granted for energy products including fuel and butane gas, as well as for sugar and specified qualities of flour.

- $\quad$ Over 85 percent of the total 2011 expenditure on subsidies is expected to be spent on energy products. Subsidies for fuel and butane are determined by a pricing formula as the difference between an adjusted market price and the politically set consumer price. Consumer prices were last adjusted in 2008.

- Subsidies for food were introduced to support the consumption of staple items.
- The consumption of sugar per person is very high. The price for sugar has been kept constant since 2006. The subsidy for basic flour is targeted to the poor. The subsidized volume is fixed, and the subsidized products are distributed by criteria that should channel the product mostly to the poor. Since 2007, following widespread protests, subsidies are also provided for the flour used for the production of standard bread.

Food subsidies are less costly and better targeted than subsidies for fuel and butane. The need for reform of energy subsidies is thus more pressing than for food subsidies.

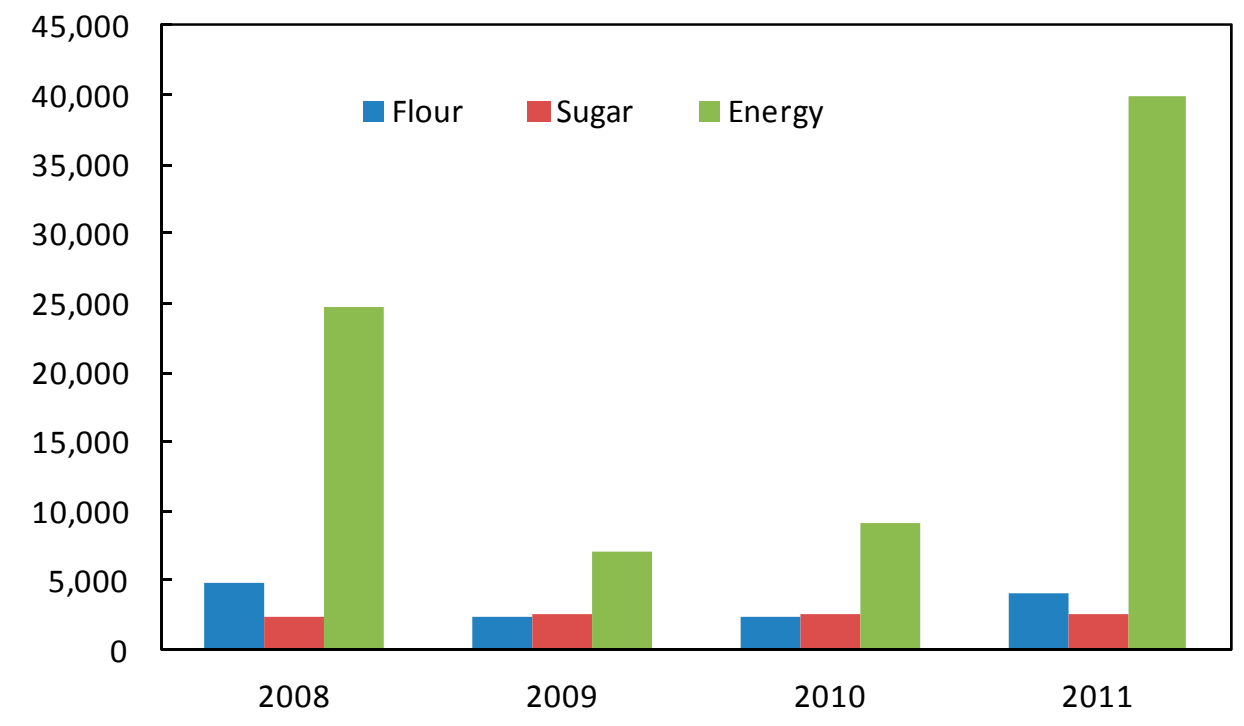




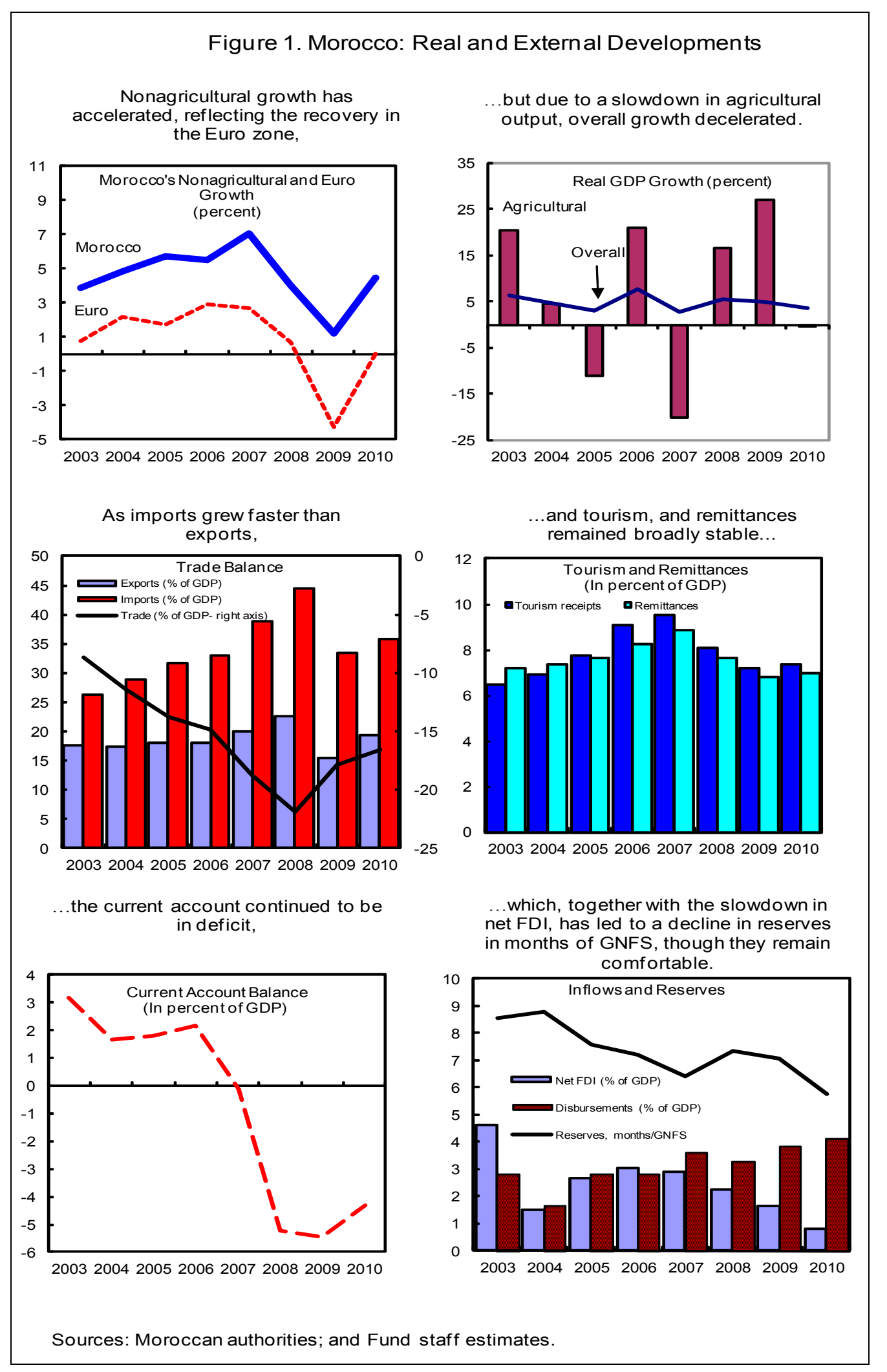


Figure 2. Morocco: Fiscal and Financial Market Developments

Revenues have fallen faster than spending...

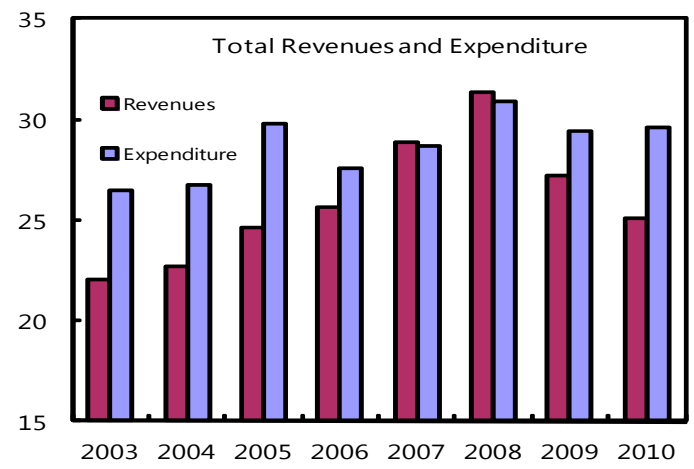

Thus, the fiscal deficit widened in 2010,

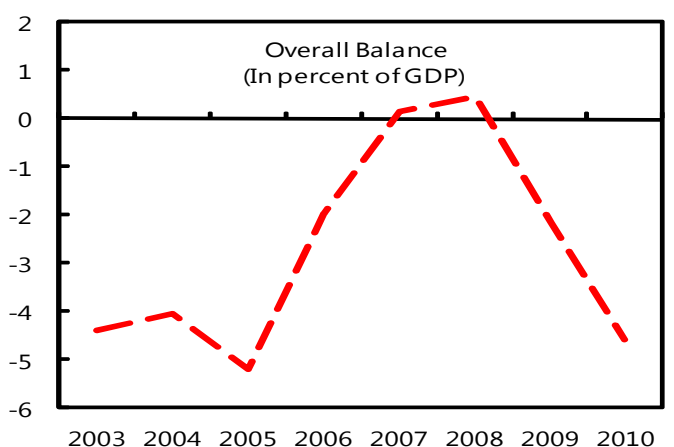

The sovereign spread has remained stable despite the uncertainty in neighboring

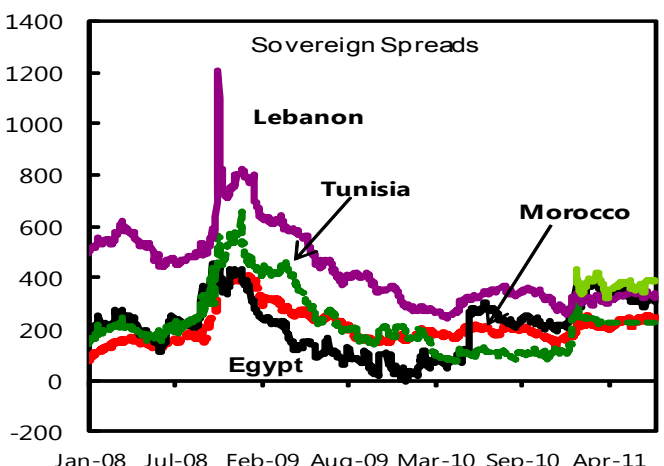

...with an increase in subsidies, partly compensated by a reduction in capital spending.
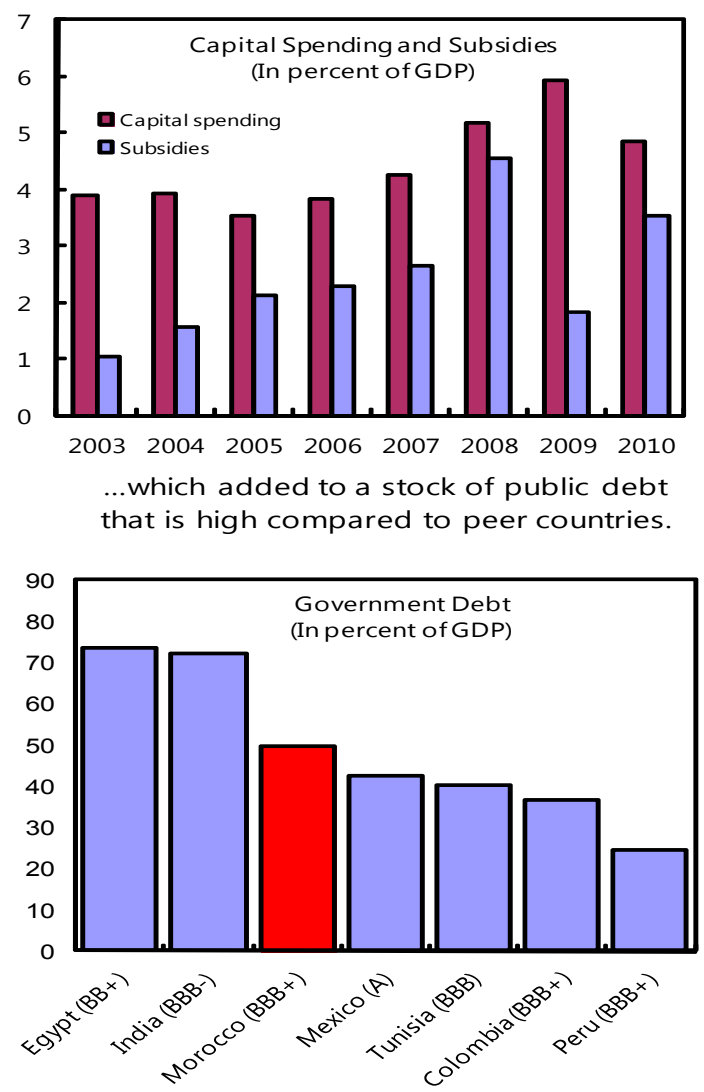

... but the stock market index saw a small decline.

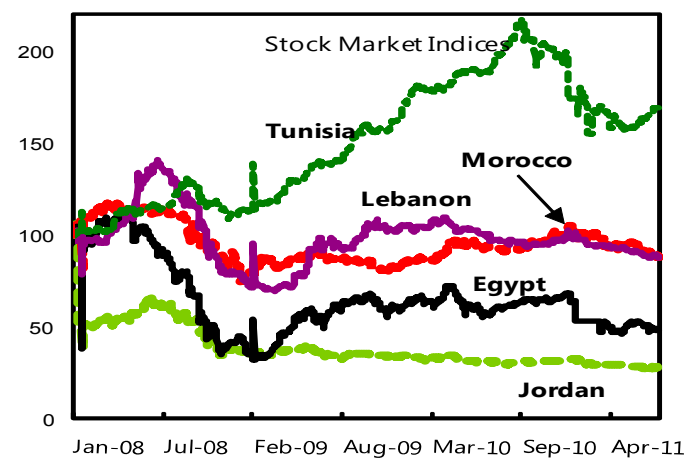

Sources: Moroccan authorities; and Fund staff estimates. 
Figure 3. Morocco: Monetary and Financial Sector Developments

Inflationary pressures have recently fallen due to a sharp decrease in food

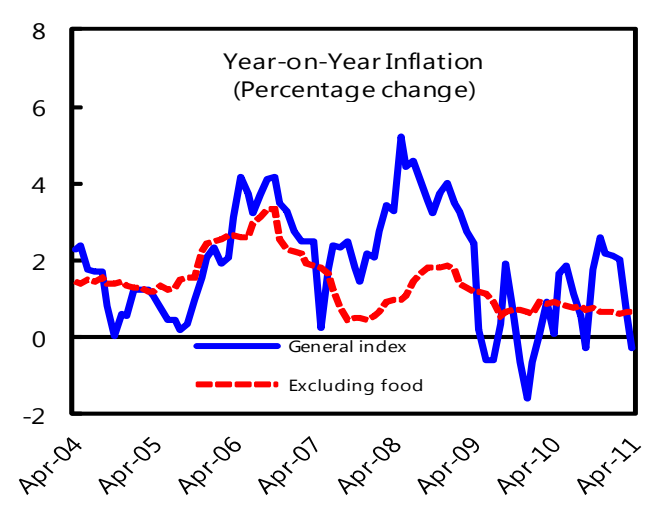

NPLs have fallen relative to earlier years,

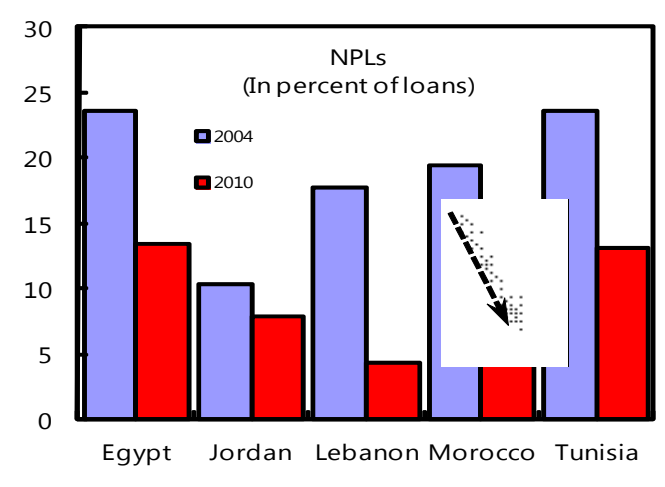

Banks are increasing capital, albeit from a low level,

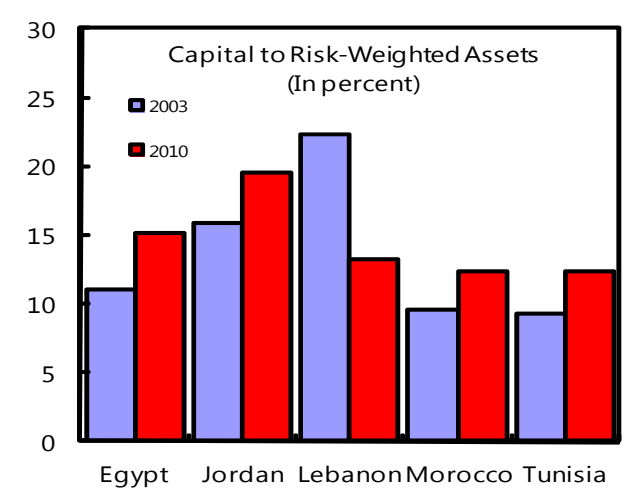

and monetary growth remained stable while NFA recently declined.

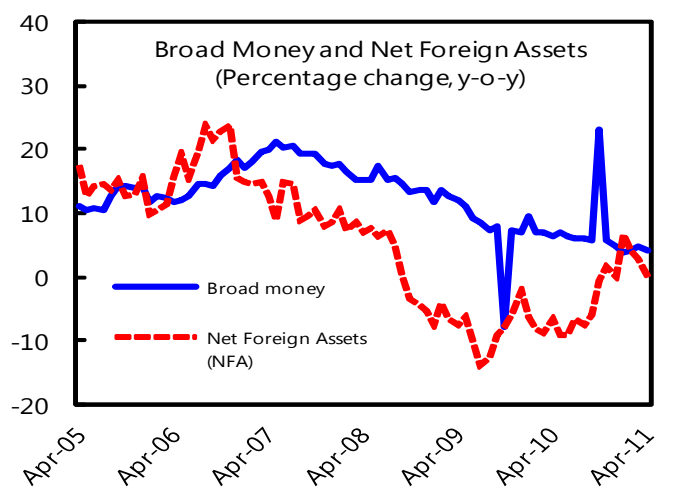

...while credit to GDP increased.

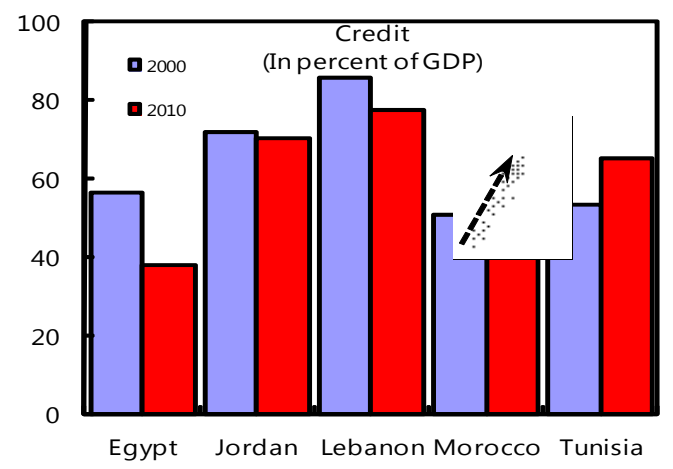


Figure 4. Morocco: Autonomous Factors, Systemic Liquidity, and Reference

The decline in systemic liquidity is driven by a decrease in official reserves and a larger-than-usual increase of currency in circulation.

\begin{tabular}{lrrrr}
\hline & $\begin{array}{r}\text { Changes in Autonomous Factors } \\
\text { Circulation }\end{array}$ & $\begin{array}{r}\text { Governement } \\
\text { Net Position at } \\
\text { BAM }\end{array}$ & $\begin{array}{r}\text { Net Foreign Asset } \\
\text { (BAM) }\end{array}$ & $\begin{array}{r}\text { Other Factors } \\
\begin{array}{r}\text { Systemic } \\
\text { Liquidity }\end{array}\end{array}$ \\
\hline Dec. 2006 to May 2007 & $-1,572$ & $-2,487$ & -266 & -321 \\
Dec. 2007 to May 2008 & $-2,615$ & $-1,373$ & 4,716 & $-1,501$ \\
Dec. 2008 to May 2009 & 975 & 3,786 & 2,456 & 496 \\
Dec. 2009 to May 2010 & -173 & 396 & $-6,279$ & 3,404 \\
Average 2006-2010 & -846 & 81 & 157 & -958 \\
Dec. 2010 to May 2011 & 3,018 & -348 & $-11,335$ & $-6,671$ \\
\hline
\end{tabular}

Systemic liquidity reached a low point, triggering multiple cuts in the reserve requirement.

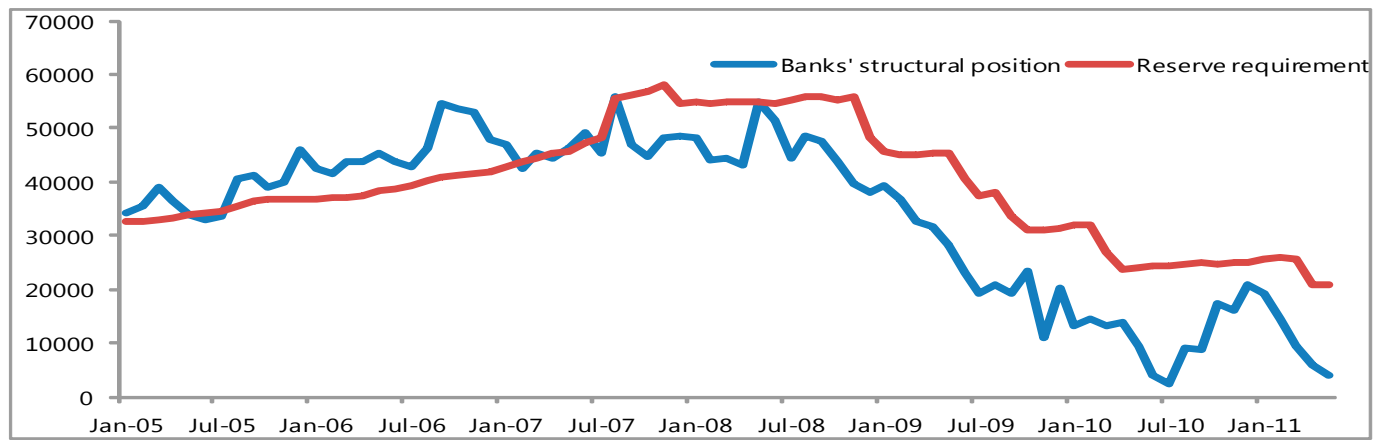

Banks' dependence on BAM refinancing increased.

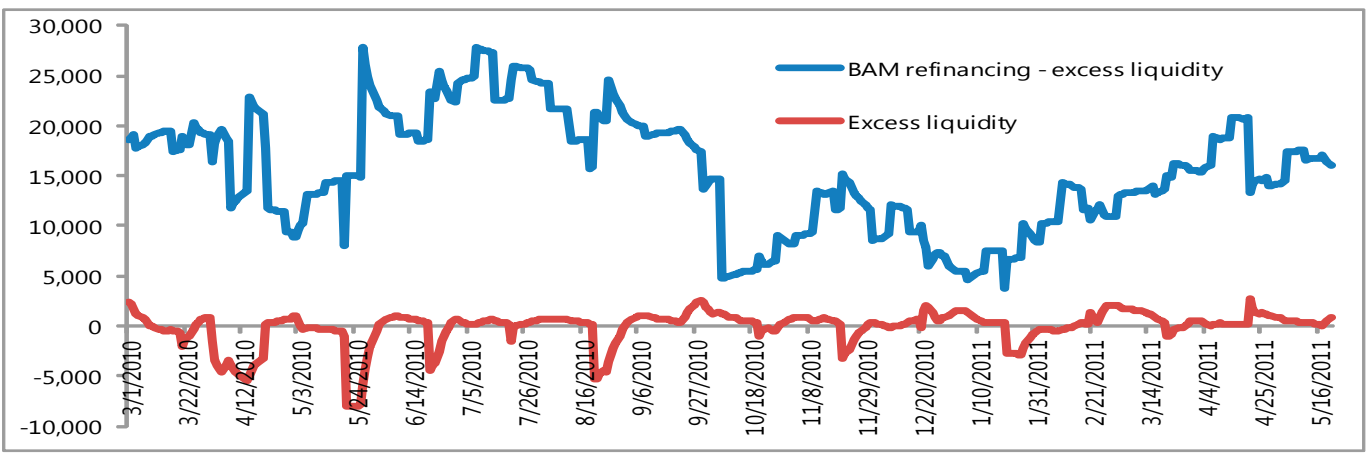

BAM's benchmark interest rate has been very stable over the last 10 years.

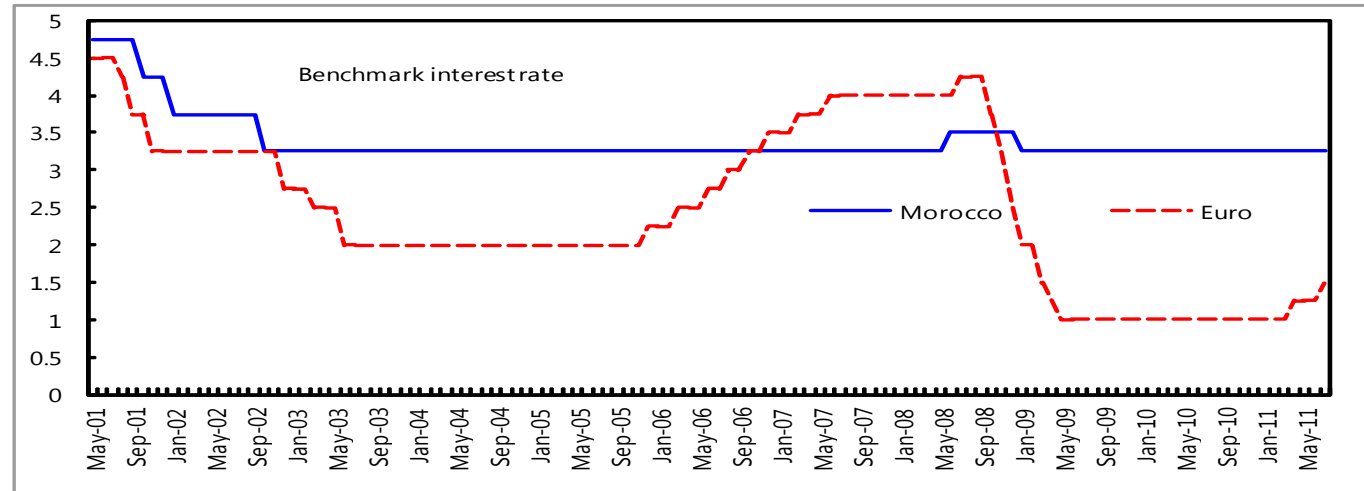

Source: BAM. 
Figure 5. Morocco: Real Effective Exchange Rate Indices and Competitiveness

The CPI and ULC-based REERs...

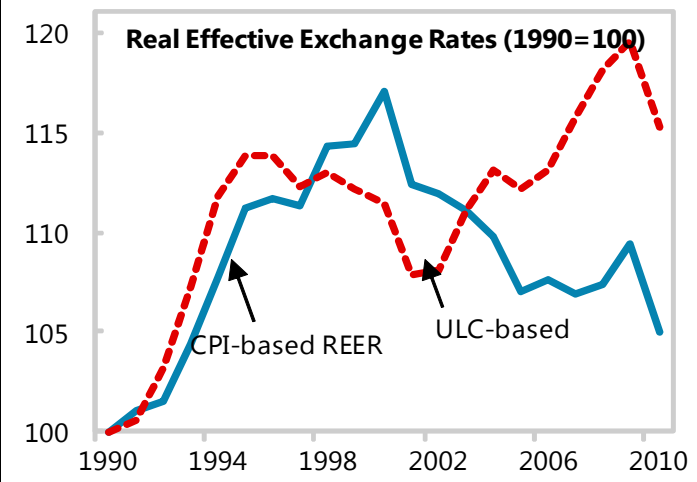

...... the PPI-based REER and ...

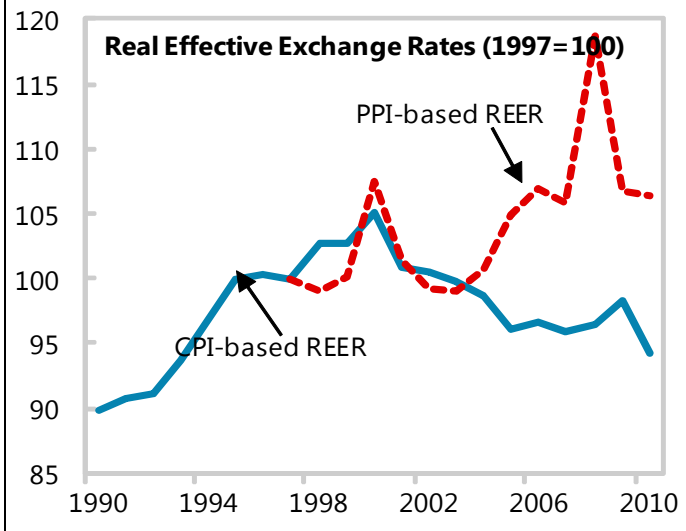

Labor productivity in Morocco has been growing ...

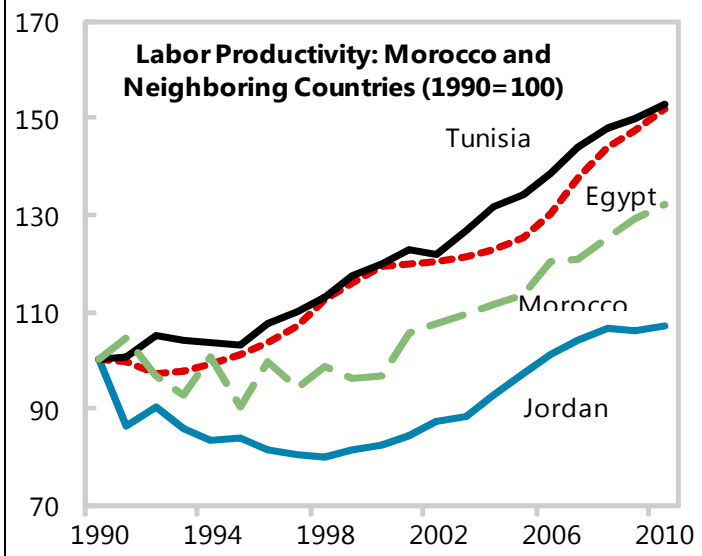

and the REER based on labor productivity show a depreciation of the REER in 2010, while...

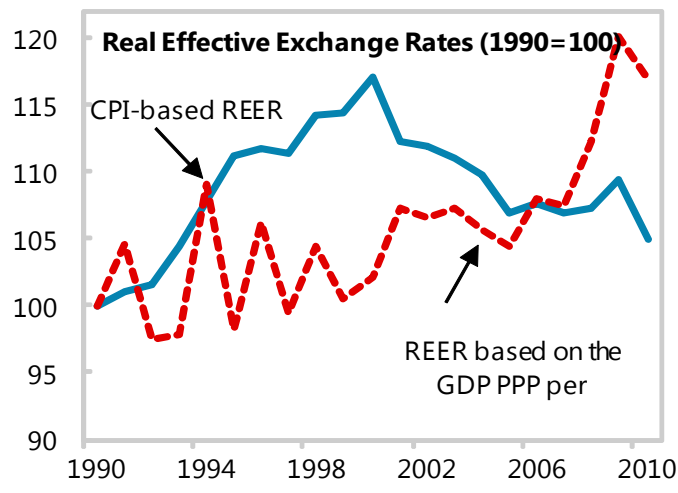

... the internal terms of trade point to a less steep decline.

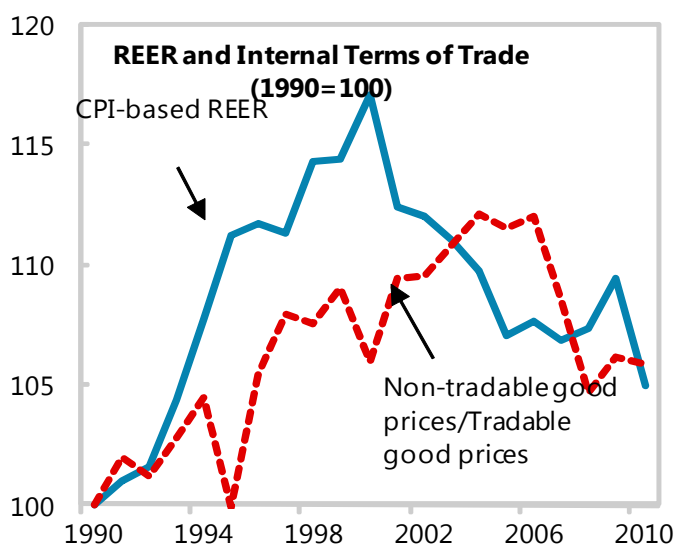

... but productivity gains are still lagging compared to key competitors.

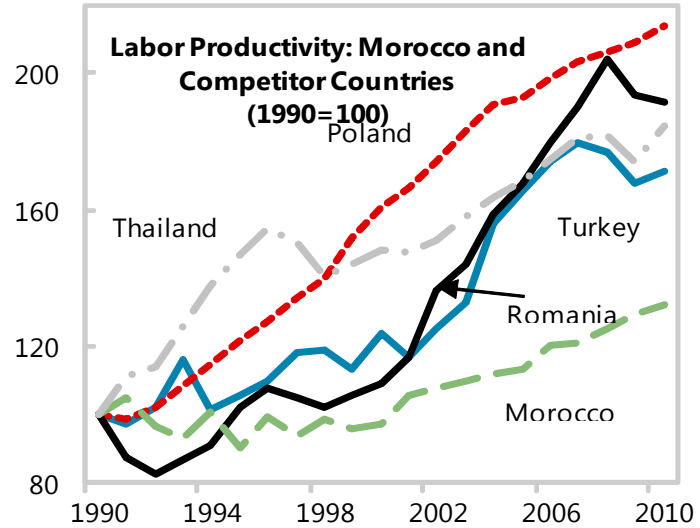

Sources: The Conference Board and Groningen Growth and Development Centre; Moroccan authorities; and staff calculations. 
Figure 6. Morocco: Cross-Country Comparisons: Social Indicators

Unemployment remains particularly high in urban areas,...

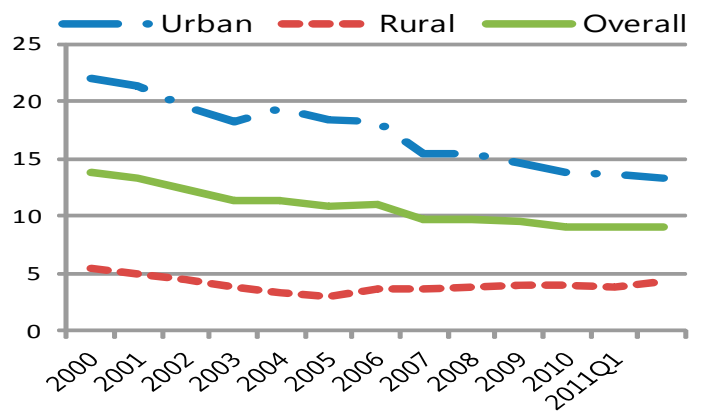

... and the young.

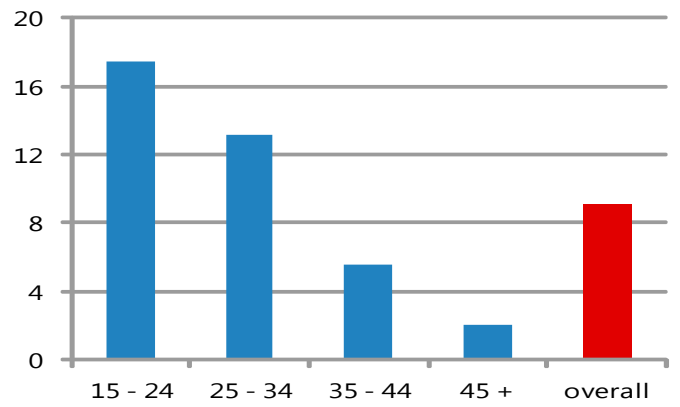

...but health...

Mortality rate (per 1,000) 2009 or latest available data

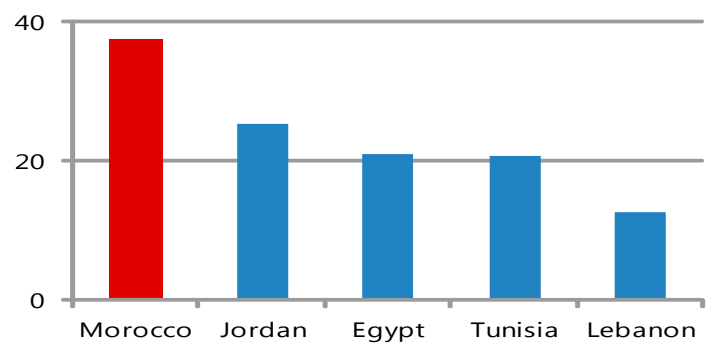

...among the educated ...

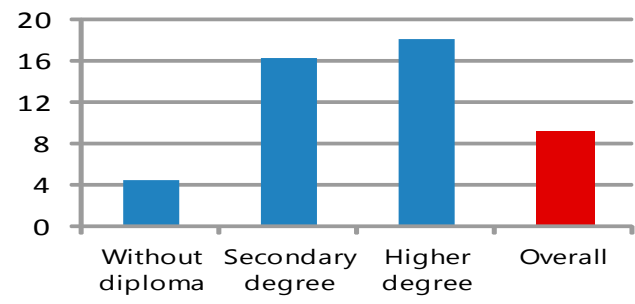

Poverty rate has fallen substantially,...

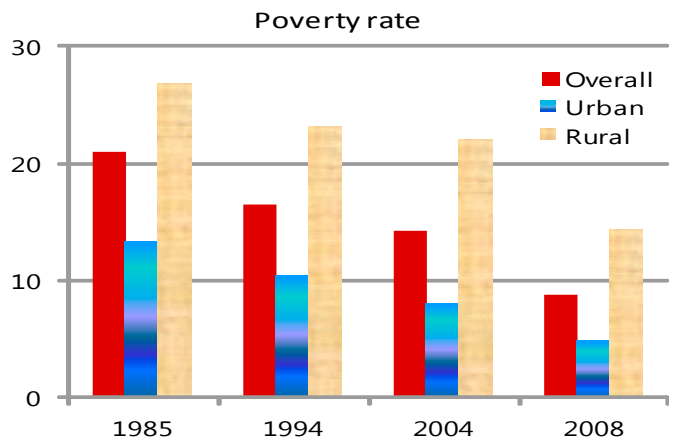

.... and education indicators need to be improved.

Literacy rate (\%), 2010 or latest available data

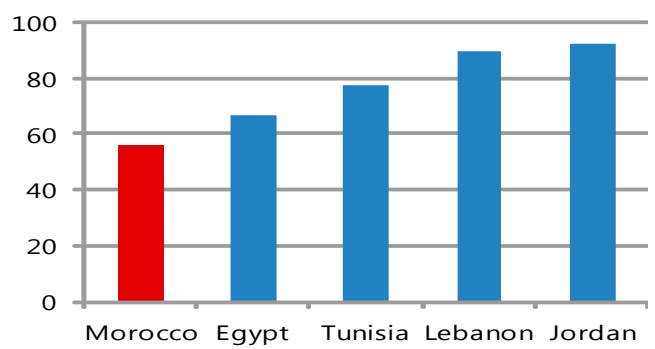

Sources: World Development Indicators (WDI) database; and Moroccan authorities. 


\section{Figure 7. Morocco: External Debt Sustainability: Bound Tests 1/ 2/ (External debt in percent of GDP)}

Baseline and historical scenarios

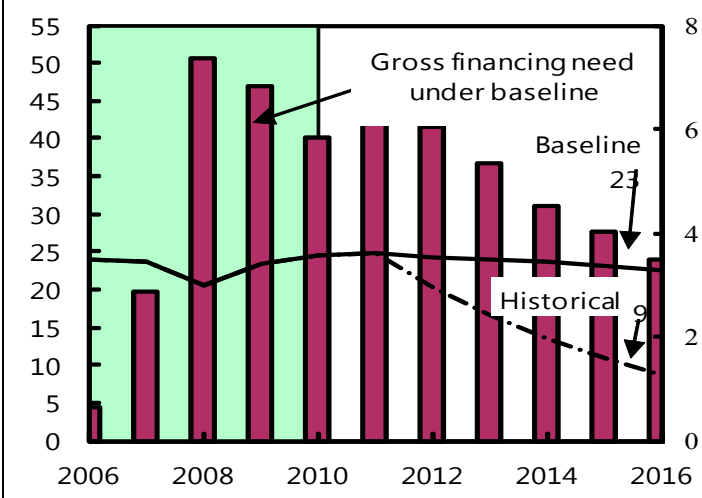

Growth shock (in percent per year)

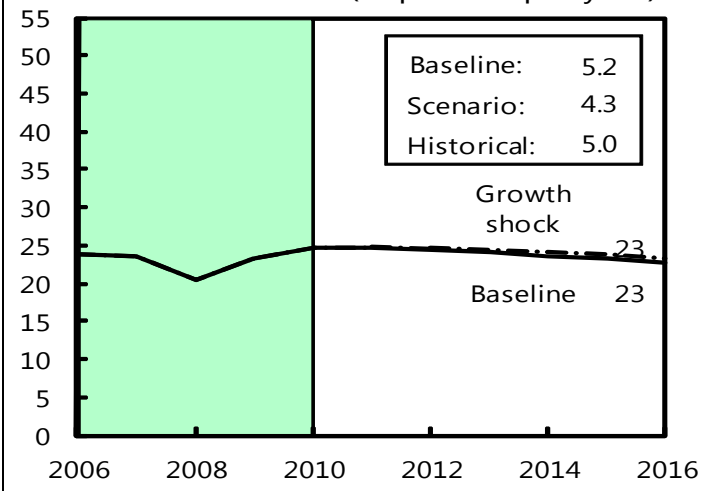

Combined shock 3/

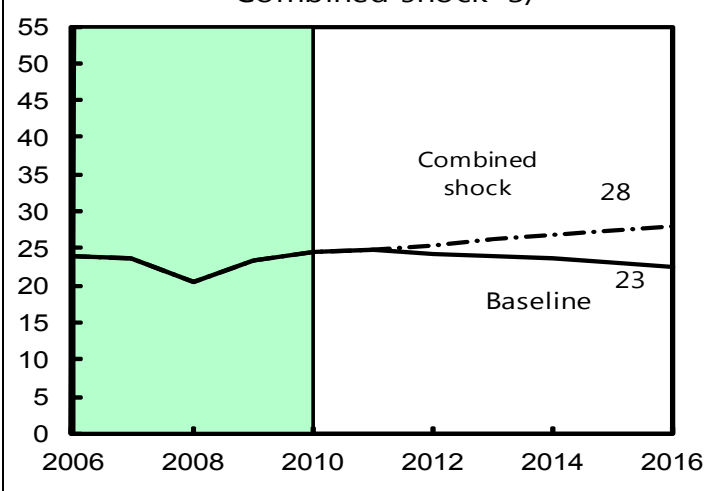

Interest rate shock (in percent)
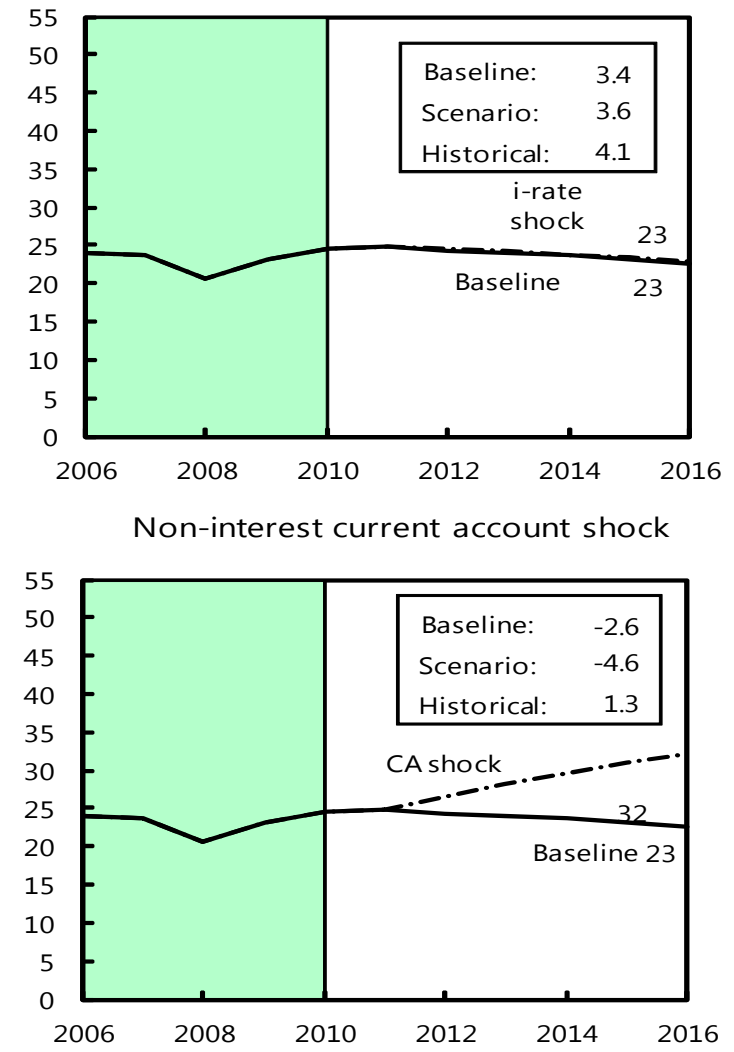

Real depreciation shock 4/

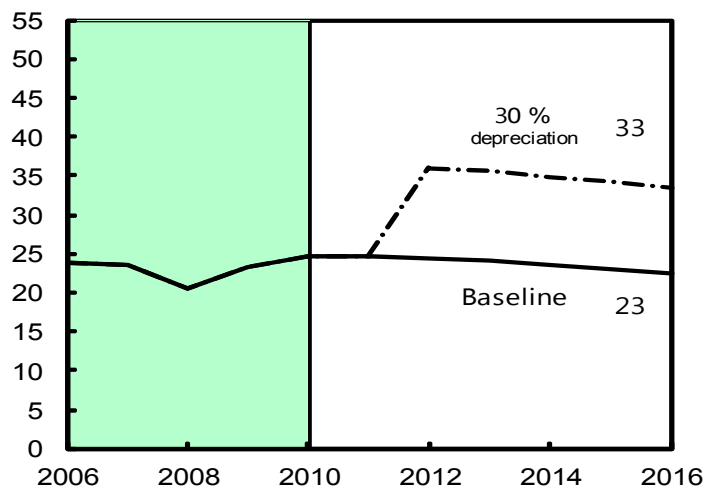

Sources: International Monetary Fund, Country desk data, and staff estimates.

1 / Shaded areas represent actual data. Individual shocks are permanent one-half standard deviation shocks. Figures in the boxes represent average projections for the respective variables in the baseline and scenario being presented. Ten-year historical average for the variable is also shown.

2/ For historical scenarios, the historical averages are calculated over the ten-year period, and the information is used to project debt dynamics five years ahead.

3/ Permanent 1/4 standard deviation shocks applied to real interest rate, growth rate, and current account balance.

4/ One-time real depreciation of 30 percent occurs in 2010. 


\section{Figure 8. Morocco: Public Debt Sustainability: Bound Tests 1/2/ (Public debt in percent of GDP)}
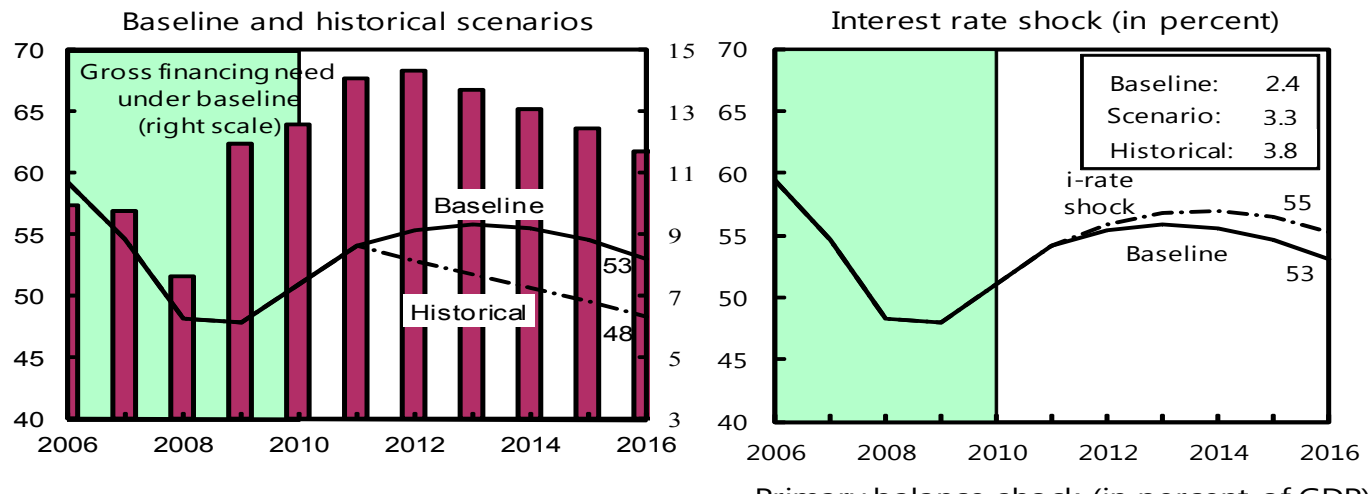

Growth shock

Primary balance shock (in percent of GDP) and
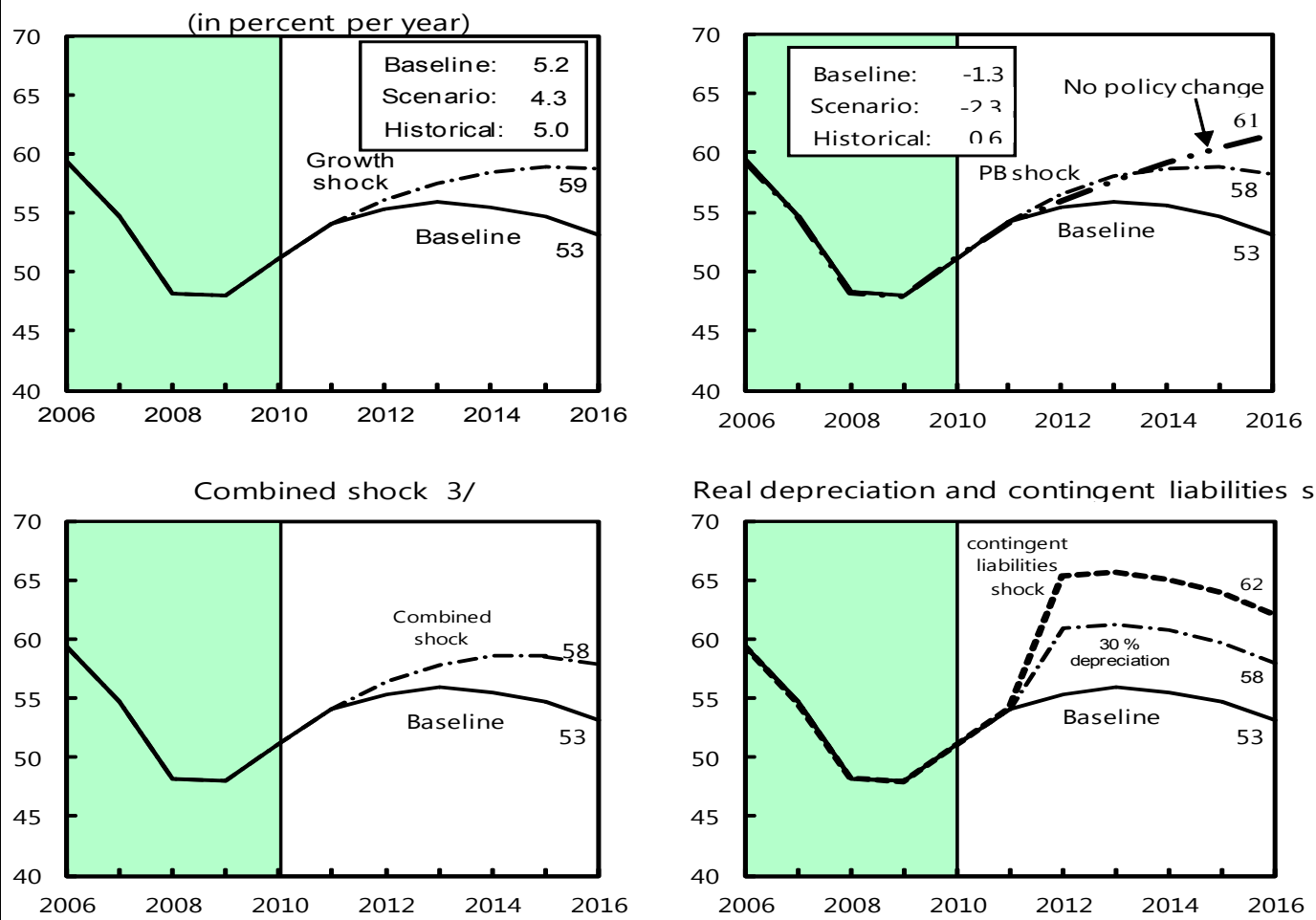

Sources: International Monetary Fund, country desk data, and staff estimates.

1/ Shaded areas represent actual data. Individual shocks are permanent one-half standard

deviation shocks. Figures in the boxes represent average projections for the respective variables in the baseline and scenario being presented. Ten-year historical average for the variable is also shown.

2/ For historical scenarios, the historical averages are calculated over the ten-year period, and the information is used to project debt dynamics five years ahead.

3/ Permanent 1/4 standard deviation shocks applied to real interest rate, growth rate, and primary balance.

4/One-time real depreciation of 30 percent and 10 percent of GDP shock to contingent liabilities occur in 2010, with real depreciation defined as nominal depreciation (measured by percentage fall in dollar value of local currency) minus domestic inflation (based on GDP deflator). 


\begin{tabular}{|c|c|c|c|c|c|c|c|c|}
\hline & \multicolumn{3}{|c|}{ Prel. } & \multicolumn{4}{|c|}{ Proj. } & \multirow[b]{2}{*}{2016} \\
\hline & 2009 & 2010 & 2011 & 2012 & 2013 & 2014 & 2015 & \\
\hline & \multicolumn{8}{|c|}{ (Annual percentage change) } \\
\hline \multicolumn{9}{|l|}{ Output and Prices } \\
\hline Real GDP (market price) & 4.8 & 3.7 & 4.6 & 4.6 & 4.9 & 5.2 & 5.5 & 5.9 \\
\hline Real nonagricultural GDP (market price) & 1.2 & 4.5 & 5.0 & 4.9 & 4.9 & 5.3 & 5.6 & 6.0 \\
\hline Consumer prices (end of period) & -1.6 & 2.2 & 2.0 & 2.7 & 2.6 & 2.6 & 2.6 & 2.6 \\
\hline \multirow[t]{2}{*}{ Consumer prices (period average) } & 0.9 & 1.0 & 1.5 & 2.7 & 2.6 & 2.6 & 2.6 & 2.6 \\
\hline & \multicolumn{8}{|c|}{ (In percent of GDP) } \\
\hline \multicolumn{9}{|l|}{ Investment and Saving } \\
\hline Gross capital formation & 35.6 & 35.1 & 35.0 & 34.8 & 35.0 & 35.1 & 35.4 & 35.3 \\
\hline Of which: Nongovernment & 31.9 & 32.0 & 31.8 & 31.8 & 32.0 & 32.1 & 32.4 & 32.3 \\
\hline Gross national savings & 30.2 & 30.8 & 29.8 & 30.8 & 31.5 & 32.0 & 32.7 & 33.0 \\
\hline \multirow[t]{2}{*}{ Of which: Nongovernment } & 25.1 & 27.5 & 28.1 & 28.1 & 28.2 & 28.0 & 28.2 & 28.0 \\
\hline & \multicolumn{8}{|c|}{ (In percent of GDP) } \\
\hline \multicolumn{9}{|l|}{ Public Finances } \\
\hline Revenue 1/ & 27.2 & 25.1 & 25.6 & 25.2 & 25.5 & 25.5 & 25.6 & 25.6 \\
\hline Expenditure & 29.4 & 29.7 & 31.3 & 30.5 & 30.2 & 29.6 & 29.1 & 28.6 \\
\hline Budget balance & -2.2 & -4.6 & -5.7 & -5.3 & -4.7 & -4.0 & -3.5 & -3.0 \\
\hline Primary balance & 0.0 & -2.4 & -3.6 & -2.7 & -2.0 & -1.4 & -0.9 & -0.5 \\
\hline \multirow[t]{2}{*}{ Total government debt } & 47.9 & 51.1 & 54.2 & 55.5 & 56.0 & 55.8 & 54.9 & 53.5 \\
\hline & \multicolumn{8}{|c|}{ (Annual percentage change, unless otherwise indicated) } \\
\hline \multicolumn{9}{|l|}{ Monetary Sector } \\
\hline Credit to the private sector 2 / & 10.4 & 7.4 & 6.2 & $\ldots$ & $\ldots$ & $\ldots$ & $\ldots$ & $\ldots$ \\
\hline Broad money & 7.0 & 4.8 & 4.2 & $\ldots$ & $\ldots$ & $\ldots$ & $\ldots$ & $\ldots$ \\
\hline Velocity of broad money & 0.8 & 0.8 & 0.9 & $\ldots$ & $\ldots$ & $\ldots$ & $\ldots$ & $\ldots$ \\
\hline Three-month treasury bill rate (period average, in percent) & 3.3 & 3.4 & $\ldots$ & $\ldots$ & $\ldots$ & $\ldots$ & $\ldots$ & $\ldots$ \\
\hline & \multicolumn{8}{|c|}{ (In percent of GDP, unless otherwise indicated) } \\
\hline \multicolumn{9}{|l|}{ External Sector } \\
\hline Exports of goods (in U.S. dollars, percentage change) & -30.2 & 25.3 & 25.6 & 7.0 & 4.2 & 4.1 & 4.3 & 5.8 \\
\hline Imports of goods (in U.S. dollars, percentage change) & -23.4 & 7.7 & 24.6 & 4.3 & 5.3 & 5.3 & 5.7 & 6.4 \\
\hline Merchandise trade balance & -17.9 & -16.5 & -18.3 & -17.2 & -17.1 & -17.1 & -17.0 & -16.9 \\
\hline Current account excluding official transfers & -5.9 & -4.6 & -5.9 & -4.5 & -4.0 & -3.5 & -3.1 & -2.7 \\
\hline Current account including official transfers & -5.4 & -4.3 & -5.2 & -4.0 & -3.5 & -3.1 & -2.7 & -2.3 \\
\hline Foreign direct investment & 1.6 & 0.8 & 1.0 & 1.4 & 1.6 & 1.7 & 1.9 & 2.0 \\
\hline Total external debt & 23.3 & 24.6 & 24.8 & 24.4 & 24.1 & 23.6 & 23.1 & 22.6 \\
\hline Gross reserves (in billions of U.S. dollars) $3 /$ & 23.6 & 23.6 & 23.4 & 23.6 & 23.9 & 24.8 & 26.3 & 28.6 \\
\hline In months of next year imports of goods and services & 7.1 & 5.8 & 5.5 & 5.2 & 5.0 & 4.9 & 4.9 & \\
\hline $\begin{array}{l}\text { In percent of short-term external debt (on remaining } \\
\text { maturity basis) }\end{array}$ & 1,793 & 1,538 & 1,521 & 1,537 & 1,556 & 1,614 & 1,710 & 1,859 \\
\hline \multicolumn{9}{|l|}{ Memorandum Items: } \\
\hline Nominal GDP (in billions of U.S. dollars) & 90.9 & 90.8 & 101.8 & 109.2 & 116.8 & 125.3 & 134.7 & 145.4 \\
\hline Unemployment rate (in percent) & 9.1 & 9.1 & $\ldots$ & $\ldots$ & $\ldots$ & $\ldots$ & $\ldots$ & $\ldots$ \\
\hline Net imports of energy products (in billions of U.S. dollars) & -6.7 & -8.1 & -11.0 & -11.1 & -11.5 & -11.9 & -12.4 & -13.0 \\
\hline Local currency per U.S. dollar (period average) & 8.1 & 8.4 & $\ldots$ & $\ldots$ & $\ldots$ & $\ldots$ & $\ldots$ & $\ldots$ \\
\hline $\begin{array}{l}\text { Real effective exchange rate (annual average, } \\
\text { percentage change) }\end{array}$ & 1.9 & -4.1 & $\ldots$ & $\ldots$ & $\ldots$ & $\ldots$ & $\ldots$ & $\ldots$ \\
\hline \multicolumn{9}{|l|}{ Sources: Moroccan authorities; and Fund staff estimates. } \\
\hline \multicolumn{9}{|c|}{$\begin{array}{l}\text { 1/ Includes changes in the balance of other special treasury accounts. } \\
2 \text { Includes credit to public enterprises. } \\
3 \text { / As of } 2009 \text {, reserves include the new SDR allocation. }\end{array}$} \\
\hline
\end{tabular}




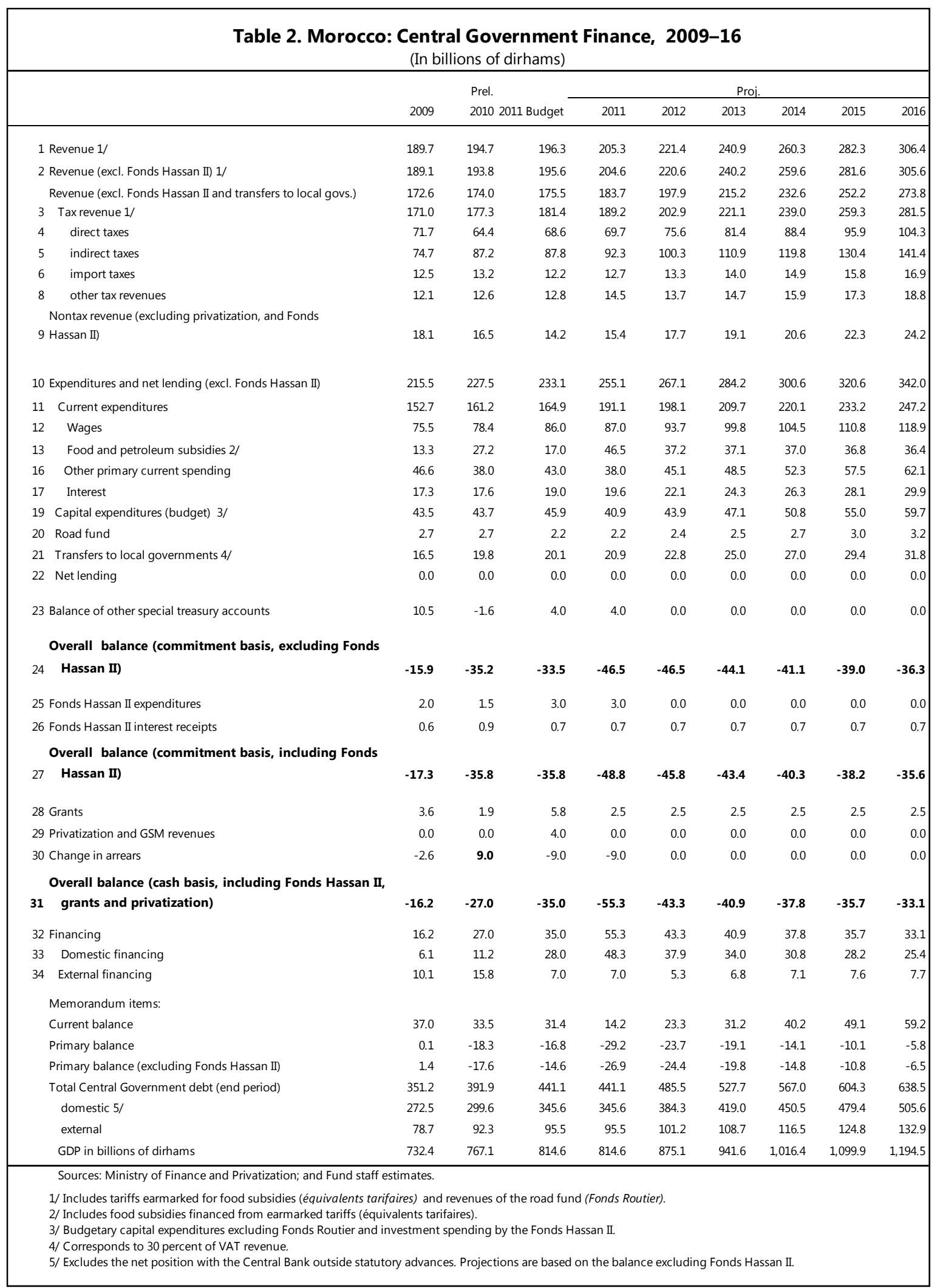


Table 3. Morocco: Central Government Finance, 2009-16 (In percent of GDP)

\begin{tabular}{|c|c|c|c|c|c|c|c|c|c|}
\hline & \multirow[b]{2}{*}{2009} & \multicolumn{2}{|l|}{ Prel. } & \multicolumn{6}{|c|}{ Proj. } \\
\hline & & 2010 & 2011 Budget & 2011 & 2012 & 2013 & 2014 & 2015 & 2016 \\
\hline Revenue 1/ & 25.9 & 25.4 & 24.1 & 25.2 & 25.3 & 25.6 & 25.6 & 25.7 & 25.6 \\
\hline Revenue (excl. Fonds Hassan II) 1/ & 25.8 & 25.3 & 24.0 & 25.1 & 25.2 & 25.5 & 25.5 & 25.6 & 25.6 \\
\hline Revenue (excl. Fonds Hassan II and transfers to local govs.) & 23.6 & 22.7 & 21.5 & 22.6 & 22.6 & 22.9 & 22.9 & 22.9 & 22.9 \\
\hline Tax revenue $1 /$ & 23.3 & 23.1 & 22.3 & 23.2 & 23.2 & 23.5 & 23.5 & 23.6 & 23.6 \\
\hline direct taxes & 9.8 & 8.4 & 8.4 & 8.6 & 8.6 & 8.6 & 8.7 & 8.7 & 8.7 \\
\hline indirect taxes & 10.2 & 11.4 & 10.8 & 11.3 & 11.5 & 11.8 & 11.8 & 11.9 & 11.8 \\
\hline import taxes & 1.7 & 1.7 & 1.5 & 1.6 & 1.5 & 1.5 & 1.5 & 1.4 & 1.4 \\
\hline other tax revenues & 1.7 & 1.6 & 1.6 & 1.8 & 1.6 & 1.6 & 1.6 & 1.6 & 1.6 \\
\hline \multicolumn{10}{|l|}{ Nontax revenue (excluding privatization, and Fonds } \\
\hline Hassan II) & 2.5 & 2.1 & 1.7 & 1.9 & 2.0 & 2.0 & 2.0 & 2.0 & 2.0 \\
\hline Expenditures and net lending (excl. Fonds Hassan II) & 29.4 & 29.7 & 28.6 & 31.3 & 30.5 & 30.2 & 29.6 & 29.1 & 28.6 \\
\hline Current expenditures & 20.9 & 21.0 & 20.2 & 23.5 & 22.6 & 22.3 & 21.7 & 21.2 & 20.7 \\
\hline Wages & 10.3 & 10.2 & 10.6 & 10.7 & 10.7 & 10.6 & 10.3 & 10.1 & 10.0 \\
\hline Food and petroleum subsidies 2/ & 1.8 & 3.5 & 2.1 & 5.7 & 4.3 & 3.9 & 3.6 & 3.3 & 3.0 \\
\hline Other primary current spending & 6.4 & 5.0 & 5.3 & 4.7 & 5.2 & 5.2 & 5.2 & 5.2 & 5.2 \\
\hline Interest & 2.4 & 2.3 & 2.3 & 2.4 & 2.5 & 2.6 & 2.6 & 2.6 & 2.5 \\
\hline Capital expenditures (budget) 3/ & 5.9 & 5.7 & 5.6 & 5.0 & 5.0 & 5.0 & 5.0 & 5.0 & 5.0 \\
\hline Road fund & 0.4 & 0.4 & 0.3 & 0.3 & 0.3 & 0.3 & 0.3 & 0.3 & 0.3 \\
\hline Transfers to local governments 4/ & 2.3 & 2.6 & 2.5 & 2.6 & 2.6 & 2.7 & 2.7 & 2.7 & 2.7 \\
\hline Net lending & 0.0 & 0.0 & 0.0 & 0.0 & 0.0 & 0.0 & 0.0 & 0.0 & 0.0 \\
\hline Balance of other special treasury accounts & 1.4 & -0.2 & 0.5 & 0.5 & 0.0 & 0.0 & 0.0 & 0.0 & 0.0 \\
\hline \multicolumn{10}{|l|}{ Overall balance (commitment basis, excluding Fonds } \\
\hline Hassan II) & -2.2 & -4.6 & -4.1 & -5.7 & -5.3 & -4.7 & -4.0 & -3.5 & -3.0 \\
\hline Fonds Hassan II expenditures & 0.3 & 0.2 & 0.4 & 0.4 & 0.0 & 0.0 & 0.0 & 0.0 & 0.0 \\
\hline Fonds Hassan II interest receipts & 0.1 & 0.1 & 0.1 & 0.1 & 0.1 & 0.1 & 0.1 & 0.1 & 0.1 \\
\hline \multicolumn{10}{|l|}{ Overall balance (commitment basis, including Fonds } \\
\hline Hassan II) & -2.4 & -4.7 & -4.4 & -6.0 & -5.2 & -4.6 & -4.0 & -3.5 & -3.0 \\
\hline Grants & 0.5 & 0.2 & 0.7 & 0.3 & 0.3 & 0.3 & 0.2 & 0.2 & 0.2 \\
\hline Privatization and GSM revenues & 0.0 & 0.0 & 0.5 & 0.0 & 0.0 & 0.0 & 0.0 & 0.0 & 0.0 \\
\hline Change in arrears & -0.3 & 1.1 & -1.1 & -1.1 & 0.0 & 0.0 & 0.0 & 0.0 & 0.0 \\
\hline \multicolumn{10}{|l|}{ Overall balance (cash basis, including Fonds Hassan II, } \\
\hline grants and privatization) & -2.2 & -3.5 & -4.3 & -6.8 & -4.9 & -4.3 & -3.7 & -3.2 & -2.8 \\
\hline Financing & 2.2 & 3.5 & 4.3 & 6.8 & 4.9 & 4.3 & 3.7 & 3.2 & 2.8 \\
\hline Domestic financing & 0.8 & 1.5 & 3.4 & 5.9 & 4.3 & 3.6 & 3.0 & 2.6 & 2.1 \\
\hline External financing & 1.4 & 2.1 & 0.9 & 0.9 & 0.6 & 0.7 & 0.7 & 0.7 & 0.6 \\
\hline \multicolumn{10}{|l|}{ Memorandum items: } \\
\hline Current balance & 5.0 & 4.4 & 3.9 & 1.7 & 2.7 & 3.3 & 4.0 & 4.5 & 5.0 \\
\hline Primary balance & 0.0 & -2.4 & -2.1 & -3.6 & -2.7 & -2.0 & -1.4 & -0.9 & -0.5 \\
\hline Primary balance (excl. Fonds Hassan II) & 0.2 & -2.3 & -1.8 & -3.3 & -2.8 & -2.1 & -1.5 & -1.0 & -0.5 \\
\hline Total Central Government debt (end period) & 47.9 & 51.1 & 54.2 & 54.2 & 55.5 & 56.0 & 55.8 & 54.9 & 53.5 \\
\hline domestic 5/ & 37.2 & 39.1 & 42.4 & 42.4 & 43.9 & 44.5 & 44.3 & 43.6 & 42.3 \\
\hline external & 10.7 & 12.0 & 11.7 & 11.7 & 11.6 & 11.5 & 11.5 & 11.3 & 11.1 \\
\hline GDP in billions of dirhams & 688.8 & 767.1 & 814.6 & 814.6 & 875.1 & 941.6 & $1,016.4$ & $1,099.9$ & $1,194.5$ \\
\hline \multicolumn{10}{|c|}{ Sources: Ministry of Finance and Privatization; and Fund staff estimates. } \\
\hline \multicolumn{10}{|c|}{$\begin{array}{l}\text { 1/ Includes tariffs earmarked for food subsidies (équivalents tarifaires) and revenues of the road fund (Fonds } R \\
\text { 2/ Includes food subsidies financed from earmarked tariffs (équivalents tarifaires). } \\
\text { 3/ Budgetary capital expenditures excluding Fonds Routier and investment spending by the Fonds Hassan II. } \\
\text { 4/ Corresponds to } 30 \text { percent of VAT revenue. } \\
\text { 5/ Excludes the net position with the Central Bank outside statutory advances. Projections are based on the bale }\end{array}$} \\
\hline
\end{tabular}




\begin{tabular}{|c|c|c|c|c|c|c|c|c|}
\hline \multicolumn{9}{|c|}{$\begin{array}{l}\text { Table 4. Morocco: Balance of Payments, 2009-16 } \\
\text { (In billions of U.S. dollars; unless otherwise indicated) }\end{array}$} \\
\hline & \multirow[b]{2}{*}{2009} & \multirow{2}{*}{$\begin{array}{c}\text { Prel. } \\
2010 \\
\end{array}$} & & \multicolumn{3}{|c|}{ Proj. } & \multirow[b]{2}{*}{2015} & \multirow[b]{2}{*}{2016} \\
\hline & & & 2011 & 2012 & 2013 & 2014 & & \\
\hline Current account & -4.9 & -3.9 & -5.3 & -4.4 & -4.1 & -3.8 & -3.7 & -3.4 \\
\hline Trade balance & -16.3 & -15.1 & -18.6 & -18.8 & -20.0 & -21.4 & -23.0 & -24.6 \\
\hline Exports, f.o.b. & 14.0 & 17.6 & 22.1 & 23.6 & 24.6 & 25.6 & 26.7 & 28.3 \\
\hline Agriculture & 3.1 & 3.0 & 3.6 & 3.9 & 4.3 & 4.6 & 5.0 & 5.5 \\
\hline Phosphates and derived products & 2.2 & 4.2 & 5.6 & 5.8 & 5.9 & 6.1 & 6.3 & 6.6 \\
\hline Imports, f.o.b. & -30.3 & -32.6 & -40.7 & -42.4 & -44.6 & -47.0 & -49.7 & -52.8 \\
\hline Energy & -6.7 & -8.1 & -11.0 & -11.1 & -11.5 & -11.9 & -12.4 & -13.0 \\
\hline Capital goods & -8.2 & -7.9 & -9.1 & -9.9 & -10.8 & -11.9 & -13.1 & -14.6 \\
\hline Food products & -3.0 & -3.5 & -5.0 & -5.3 & -5.4 & -5.4 & -5.4 & -5.5 \\
\hline Services & 5.4 & 5.1 & 6.4 & 7.2 & 8.0 & 8.9 & 9.9 & 11.0 \\
\hline Tourism receipts & 6.6 & 6.7 & 7.6 & 8.2 & 8.9 & 9.8 & 10.7 & 11.7 \\
\hline Income & -1.5 & -1.3 & -1.7 & -1.7 & -1.7 & -1.7 & -1.8 & -1.8 \\
\hline Transfers & 7.4 & 7.3 & 8.5 & 8.9 & 9.6 & 10.3 & 11.1 & 12.0 \\
\hline Private transfers (net) & 7.0 & 7.0 & 7.8 & 8.4 & 9.1 & 9.8 & 10.6 & 11.5 \\
\hline Workers' remittances & 6.2 & 6.4 & 7.1 & 7.7 & 8.3 & 9.1 & 9.9 & 10.7 \\
\hline Official grants (net) & 0.4 & 0.2 & 0.6 & 0.5 & 0.5 & 0.5 & 0.5 & 0.5 \\
\hline Capital account & 0.0 & 0.0 & 0.0 & 0.0 & 0.0 & 0.0 & 0.0 & 0.0 \\
\hline Financial account & 5.3 & 5.3 & 4.0 & 4.7 & 4.6 & 5.0 & 5.4 & 5.9 \\
\hline Direct investment & 1.5 & 0.7 & 1.0 & 1.5 & 1.8 & 2.2 & 2.5 & 3.0 \\
\hline Privatization & 0.0 & 0.0 & 0.0 & 0.0 & 0.0 & 0.0 & 0.0 & 0.0 \\
\hline Portfolio investment & 0.0 & 0.1 & 0.1 & 0.1 & 0.1 & 0.1 & 0.1 & 0.1 \\
\hline Other & 3.8 & 4.5 & 2.8 & 3.0 & 2.6 & 2.7 & 2.7 & 2.8 \\
\hline Private & 1.4 & 2.0 & 0.9 & 1.5 & 0.9 & 0.9 & 0.9 & 1.0 \\
\hline Public medium-and long-term loans (net) & 2.4 & 2.5 & 1.9 & 1.6 & 1.7 & 1.7 & 1.8 & 1.8 \\
\hline Disbursements & 3.5 & 3.8 & 3.4 & 3.4 & 3.4 & 3.3 & 3.3 & 3.3 \\
\hline Amortization & -1.1 & -1.3 & -1.5 & -1.8 & -1.6 & -1.6 & -1.5 & -1.5 \\
\hline Reserve asset accumulation (-increase) & 0.2 & -1.2 & 1.4 & -0.3 & -0.5 & -1.1 & -1.7 & -2.5 \\
\hline \multirow[t]{2}{*}{ Errors and omissions } & -0.5 & -0.2 & 0.0 & 0.0 & 0.0 & 0.0 & 0.0 & 0.0 \\
\hline & \multicolumn{7}{|c|}{ (In percent of GDP) } & \\
\hline Current account & -5.4 & -4.3 & -5.2 & -4.0 & -3.5 & -3.1 & -2.7 & -2.3 \\
\hline Trade balance & -17.9 & -16.6 & -18.3 & -17.2 & -17.1 & -17.1 & -17.0 & -16.9 \\
\hline Services & 5.9 & 5.6 & 6.3 & 6.6 & 6.8 & 7.1 & 7.4 & 7.6 \\
\hline Income & -1.6 & -1.4 & -1.6 & -1.5 & -1.4 & -1.4 & -1.3 & -1.3 \\
\hline Transfers & 8.1 & 8.0 & 8.3 & 8.2 & 8.2 & 8.2 & 8.3 & 8.2 \\
\hline Capital account & 0.0 & 0.0 & 0.0 & 0.0 & 0.0 & 0.0 & 0.0 & 0.0 \\
\hline Financial account & 5.8 & 5.8 & 3.9 & 4.3 & 3.9 & 4.0 & 4.0 & 4.1 \\
\hline Direct investment & 1.6 & 0.8 & 1.0 & 1.4 & 1.6 & 1.7 & 1.9 & 2.0 \\
\hline Portfolio investment & 0.0 & 0.1 & 0.1 & 0.1 & 0.1 & 0.1 & 0.1 & 0.1 \\
\hline Other & 4.2 & 4.9 & 2.8 & 2.8 & 2.3 & 2.1 & 2.0 & 1.9 \\
\hline \multicolumn{9}{|l|}{ Memorandum items: } \\
\hline Exports of goods and services (percentage growth) & -4.7 & 23.0 & 12.6 & 7.3 & 5.0 & 5.2 & 5.3 & 5.3 \\
\hline Imports of goods and services (percentage growth) & 13.8 & -1.6 & 9.4 & 4.9 & 5.4 & 5.8 & 5.9 & 6.1 \\
\hline Current account balance excluding official grants (percent of GDP) & -5.9 & -4.6 & -5.9 & -4.5 & -4.0 & -3.5 & -3.1 & -2.7 \\
\hline Terms of trade (percentage change) & 10.9 & -15.0 & -3.7 & -0.4 & -0.6 & -0.3 & -0.3 & 0.1 \\
\hline Gross official reserves $1 /$ & 23.6 & 23.6 & 23.4 & 23.6 & 23.9 & 24.8 & 26.3 & 28.6 \\
\hline In months of prospective imports of GNFS & 7.1 & 5.8 & 5.5 & 5.2 & 5.0 & 4.9 & 4.9 & $\ldots$ \\
\hline Debt service (percent of export of GNFS and MRE) 2/ & 6.1 & 5.5 & 5.1 & 5.6 & 5.0 & 4.7 & 4.5 & 4.3 \\
\hline External public and publicly guaranteed debt (percent of GDP) & 20.8 & 22.7 & 23.2 & 23.0 & 22.9 & 22.6 & 22.2 & 21.7 \\
\hline DHs per US\$, period average & 8.1 & 8.4 & $\ldots$ & $\ldots$ & $\ldots$ & $\ldots$ & $\ldots$ & $\ldots$ \\
\hline GDP (\$) & 90.9 & 90.8 & 101.8 & 109.2 & 116.8 & 125.3 & 134.7 & 145.4 \\
\hline Oil price (US\$/barrel) & 61.8 & 79.0 & 103.2 & 100.0 & 99.5 & 97.5 & 96.5 & 95.5 \\
\hline \multicolumn{9}{|c|}{$\begin{array}{l}\text { Sources: Ministry of Finance; Office des Changes; and Fund staff estimates and projections. } \\
\text { 1/ Excluding the reserve position in the Fund. As of 2009, reserves include the new SDR allocation. } \\
\text { 2/ Public and publically guaranteed debt. }\end{array}$} \\
\hline
\end{tabular}




\begin{tabular}{|c|c|c|c|c|c|c|c|}
\hline \multicolumn{8}{|c|}{ Table 5. Morocco: Monetary Survey, 2006-12 } \\
\hline & \multirow[b]{2}{*}{2006} & \multirow[b]{2}{*}{2007} & \multirow[b]{2}{*}{2008} & \multirow[b]{2}{*}{2009} & \multirow{2}{*}{$\begin{array}{l}\text { Prel. } \\
2010 \\
\end{array}$} & \multicolumn{2}{|c|}{ Proj. } \\
\hline & & & & & & 2011 & 2012 \\
\hline & \multicolumn{7}{|c|}{ (In millions of dirhams) } \\
\hline Net foreign assets & 191,537 & 208,069 & 197,099 & 192,714 & 192,742 & 181,933 & 184,710 \\
\hline Monetary authorities & 173,766 & 188,142 & 181,715 & 176,397 & 187,672 & 177,404 & 180,042 \\
\hline Of which: Gross reserves & 176,018 & 190,635 & 184,348 & 185,334 & 197,328 & 187,060 & 189,698 \\
\hline Deposit money banks & 17,771 & 19,927 & 15,385 & 16,317 & 5,070 & 4,529 & 4,668 \\
\hline Net domestic assets & 413,019 & 501,928 & 608,886 & 669,941 & 711,498 & 760,545 & 836,423 \\
\hline Domestic credit & 423,997 & 528,718 & 632,841 & 679,754 & 725,890 & 777,098 & 839,623 \\
\hline Net credit to the government & 93,663 & 98,858 & 98,001 & 89,406 & 91,943 & 104,147 & 116,253 \\
\hline Banking system & 93,663 & 98,858 & 98,001 & 89,406 & 91,943 & 104,147 & 116,253 \\
\hline Bank Al-Maghrib & -646 & 4,336 & 6,438 & 3,332 & 3,524 & 3,278 & 2,966 \\
\hline Of which: deposits $1 /$ & $-14,634$ & $-9,451$ & $-5,083$ & $-5,047$ & $-3,962$ & $-4,207$ & $-4,520$ \\
\hline Deposit money banks & 94,309 & 94,523 & 91,563 & 86,074 & 88,419 & 100,869 & 113,288 \\
\hline Credit to the economy & 330,334 & 429,859 & 534,839 & 590,348 & 633,948 & 672,951 & 723,370 \\
\hline Other liabilities, net & 10,978 & 26,790 & 23,954 & 9,814 & 14,392 & 16,553 & 3,200 \\
\hline Broad money & 604,556 & 709,997 & 805,986 & 862,655 & 904,240 & 942,478 & $1,021,133$ \\
\hline Money & 387,583 & 459,722 & 491,842 & 528,495 & 552,289 & 571,460 & 610,872 \\
\hline Currency outside banks & 109,177 & 120,045 & 128,091 & 136,664 & 145,235 & 154,230 & 165,688 \\
\hline Demand deposits & 278,406 & 339,677 & 363,751 & 391,831 & 407,054 & 417,230 & 445,185 \\
\hline Quasi money & 209,509 & 242,320 & 302,944 & 319,405 & 334,845 & 355,584 & 391,143 \\
\hline \multirow[t]{2}{*}{ Foreign deposits } & 7,464 & 7,955 & 11,200 & 14,755 & 17,106 & 15,434 & 19,119 \\
\hline & \multicolumn{7}{|c|}{ (Annual percentage change) } \\
\hline Net foreign assets & 15.4 & 8.6 & -5.3 & -2.2 & 0.0 & -5.6 & 1.5 \\
\hline Net domestic assets & 19.5 & 21.5 & 21.3 & 10.0 & 6.2 & 6.9 & 10.0 \\
\hline Domestic credit & 16.9 & 24.7 & 19.7 & 7.4 & 6.8 & 7.1 & 8.0 \\
\hline Net credit to the government & 3.9 & 5.5 & -0.9 & -8.8 & 2.8 & 13.3 & 11.6 \\
\hline Credit to the economy & 21.2 & 30.1 & 24.4 & 10.4 & 7.4 & 6.2 & 7.5 \\
\hline Broad money & \multicolumn{7}{|c|}{ (In percent of broad money) } \\
\hline Net foreign assets & 5.0 & 2.7 & -1.5 & -0.5 & 0.0 & -1.2 & 0.3 \\
\hline Domestic credit & 12.0 & 17.3 & 14.7 & 5.8 & 5.3 & 5.7 & 6.6 \\
\hline Net credit to the government & 0.7 & 0.9 & -0.1 & -1.1 & 0.3 & 1.3 & 1.3 \\
\hline Credit to the economy & 11.3 & 16.5 & 14.8 & 6.9 & 5.1 & 4.3 & 5.3 \\
\hline Other assets net & 1.2 & -2.6 & 0.4 & 1.8 & -0.5 & -0.2 & 1.4 \\
\hline \multicolumn{8}{|l|}{ Memorandum items: } \\
\hline Velocity (GDP/M3) & 0.95 & 0.87 & 0.85 & 0.85 & 0.85 & 0.86 & 0.86 \\
\hline Velocity (non-agr. GDP/M3) & 0.81 & 0.76 & 0.74 & 0.72 & 0.73 & 0.74 & 0.74 \\
\hline Credit to economy/GDP (in percent) & 57.2 & 69.8 & 77.6 & 80.6 & 82.6 & 82.6 & 82.7 \\
\hline Credit to economy/non-agro GDP (in percent) & 67.4 & 79.4 & 89.4 & 94.4 & 96.3 & 96.1 & 95.8 \\
\hline
\end{tabular}




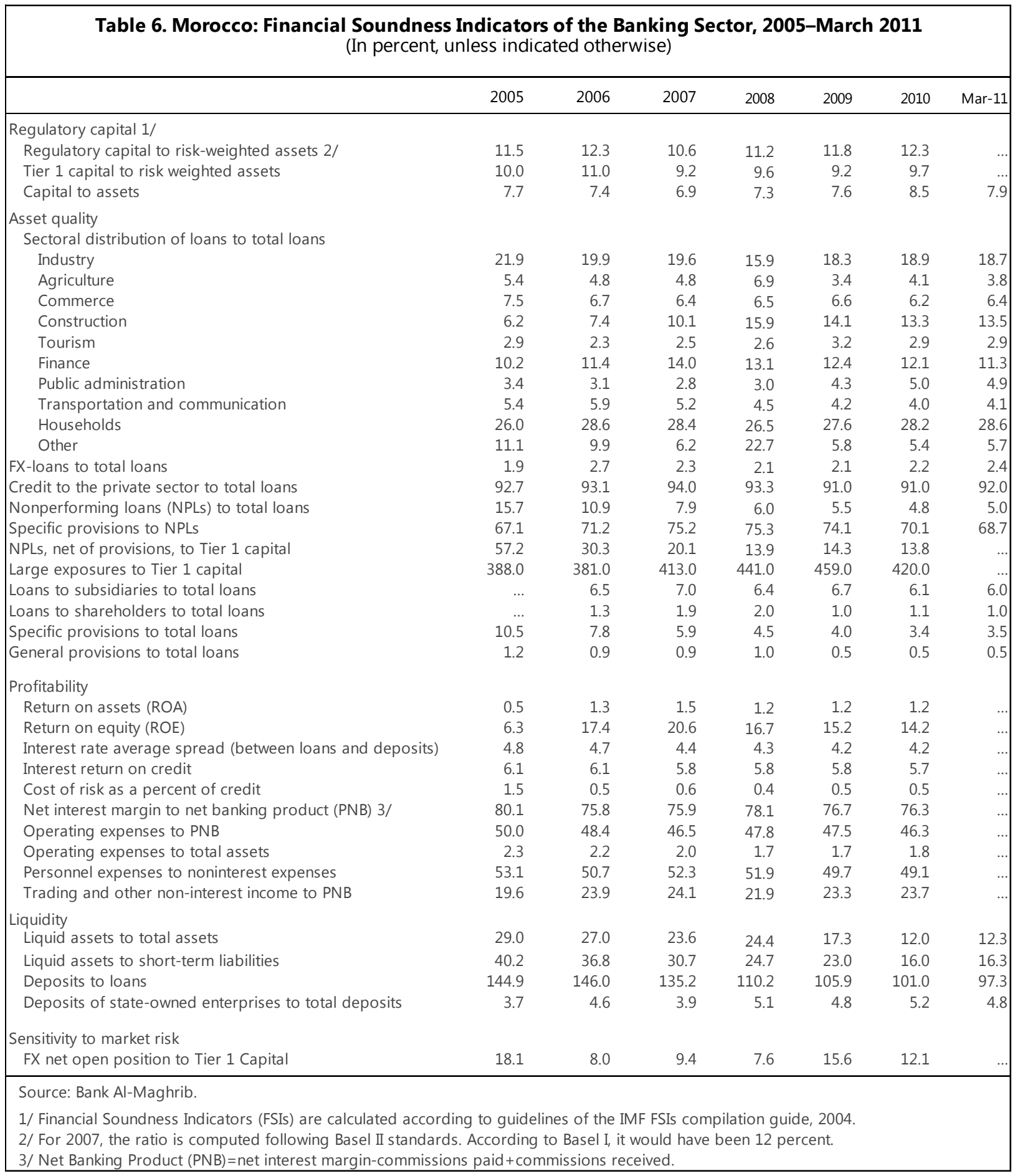




\begin{tabular}{|c|c|c|c|c|c|}
\hline & 2000 & 2006 & 2007 & 2008 & 2009 \\
\hline \multicolumn{6}{|l|}{ Labor market: } \\
\hline Employment to population ratio, $15+$, total (percent) & 45.6 & 46.6 & 46.0 & 45.8 & 45.3 \\
\hline Unemployment, total (percent of total labor force) & 13.4 & 9.7 & 9.8 & 9.6 & 9.1 \\
\hline Unemployment, male (percent of male labor force) & 13.6 & 9.7 & 9.8 & 9.5 & 9.1 \\
\hline Unemployment, female (percentof female labor force) & 12.8 & 9.7 & 9.8 & 9.8 & 9.5 \\
\hline Unemployment, youth total (percent of total labor force ages 15-24) & 19.6 & 16.6 & 17.2 & 18.3 & 17.9 \\
\hline Unemployment, youth male (percent of male labor force ages 15-24) & 21.1 & 17.5 & 17.9 & 19.1 & 18.5 \\
\hline Unemployment, youth female (percent of female labor force ages 15-24) & 15.8 & 14.1 & 15.5 & 16.2 & 16.2 \\
\hline Labor participation rate, total (percent of total population ages $15+$ ) & 53.1 & 51.3 & 51.0 & 50.6 & 49.9 \\
\hline \multicolumn{6}{|l|}{ Income, Inequality and poverty } \\
\hline Poverty headcount ratio at national poverty line (percent of population) & 15.3 & $\ldots$ & 9.0 & 8.8 & $\ldots$ \\
\hline GDP per person employed (constant 1990 PPP \$) & 8056.0 & 9829.0 & 9883.0 & 10200.0 & $\ldots$ \\
\hline GINI index & $\ldots$ & $\ldots$ & 40.9 & $\ldots$ & $\ldots$ \\
\hline Income share held by highest 20 percent & $\ldots$ & $\ldots$ & 47.9 & $\ldots$ & $\ldots$ \\
\hline Income share held by lowest 20 percent & $\ldots$ & $\ldots$ & 6.5 & $\ldots$ & $\ldots$ \\
\hline Wage and salaried workers, total (percent of total employed) & 61.6 & 43.2 & 44.8 & $\ldots$ & $\ldots$ \\
\hline Wage and salary workers, male (percent of males employed) & 58.2 & 46.8 & 48.8 & $\ldots$ & $\ldots$ \\
\hline \multicolumn{6}{|l|}{ Health and edcuation: } \\
\hline \multicolumn{6}{|l|}{ Health } \\
\hline Health expenditure, total (percent of GDP) & 4.2 & 5.2 & 5.2 & 5.3 & 5.5 \\
\hline Health expenditure, public (percent of GDP) & 1.2 & 1.7 & 1.9 & 1.9 & 1.9 \\
\hline Health expenditure, public (percent of government expenditure) & 4.0 & 5.9 & 6.9 & 6.6 & 7.0 \\
\hline Hospital beds (per 1,000 people) & $\ldots$ & 0.9 & 1.1 & $\ldots$ & 1.1 \\
\hline Life expectancy at birth, total (years) & 68.7 & 70.7 & 71.0 & 71.3 & 71.6 \\
\hline Life expectancy at birth, male (years) & 66.6 & 68.6 & 68.8 & 69.1 & 69.4 \\
\hline Life expectancy at birth, female (years) & 70.9 & 73.0 & 73.3 & 73.6 & 73.9 \\
\hline \multicolumn{6}{|l|}{ Education } \\
\hline Public spending on education, total (percent of GDP) & 5.8 & 5.5 & $\ldots$ & 5.6 & $\ldots$ \\
\hline Literacy rate, adult total (percent of people ages 15 and above) & $\ldots$ & $\ldots$ & $\ldots$ & 55.1 & 56.1 \\
\hline Primary completion rate, total (percent of relevant age group) & 56.7 & 84.0 & 83.4 & 81.3 & 80.4 \\
\hline Primary completion rate, male (percent of relevant age group) & 63.1 & 87.9 & 87.4 & 84.9 & 83.7 \\
\hline Primary completion rate, female (percent of relevant age group) & 50.1 & 80.0 & 79.2 & 77.6 & 77.0 \\
\hline Ratio of young literate females to males (percent ages 15-24) & $\ldots$ & $\ldots$ & $\ldots$ & 81.5 & 83.2 \\
\hline
\end{tabular}


Table 8. Morocco: External Debt Sustainability Framework, 2006-2016 (In percent of GDP, unless otherwise indicated)

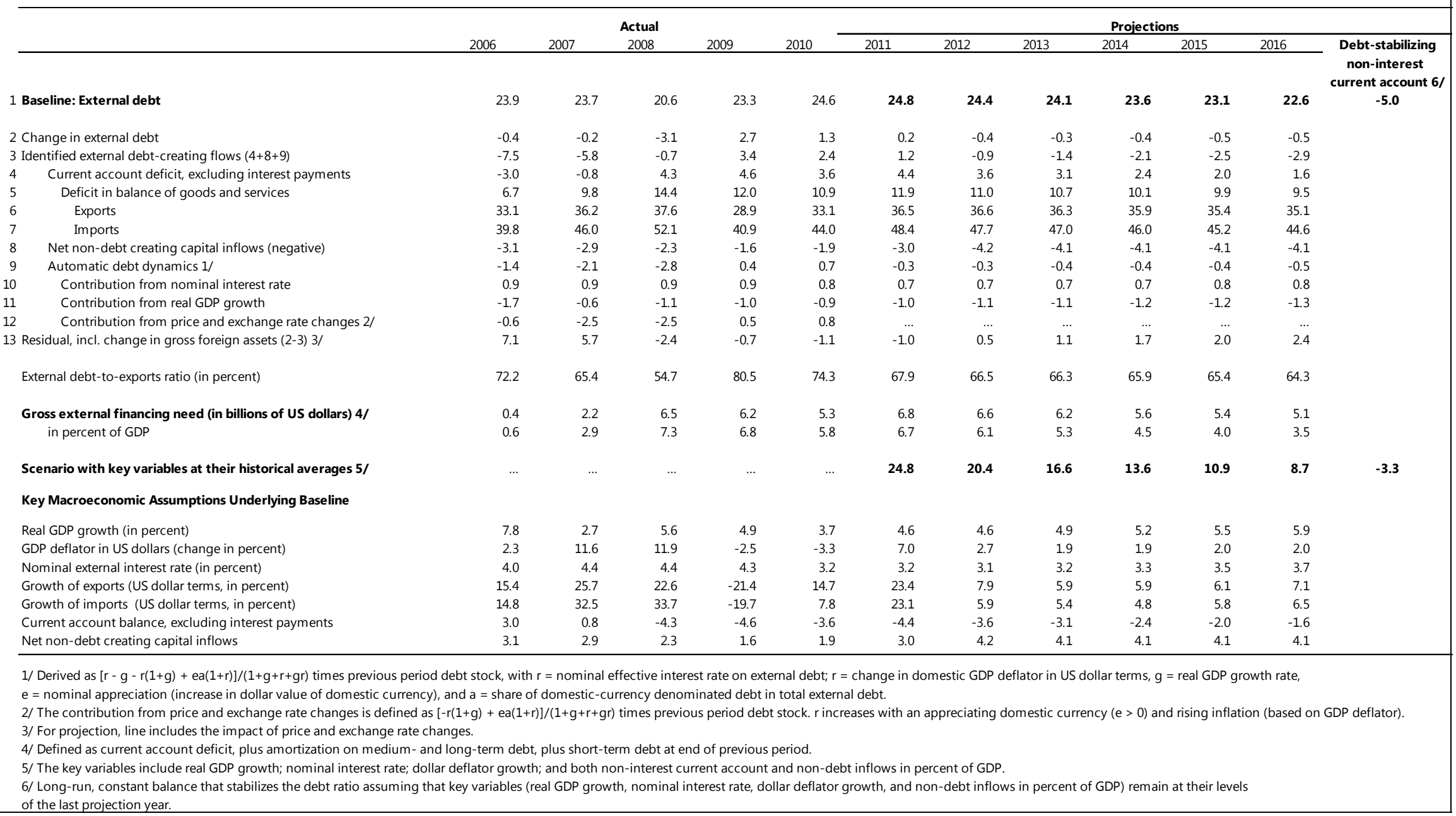


Table 9. Morocco: Public Sector Debt Sustainability Framework, 2006-16

(In percent of GDP, unless otherwise indicated)

Actual $\quad$ Projections

$\begin{array}{rrrrrrrrrrr} & & & & & & & & & & \\ 11.4 & 54.6 & 48.2 & 47.9 & 51.1 & 54.1 & 55.4 & 55.9 & 55.5 & 54.6 & 53.1 \\ & 10.7 & 9.9 & 10.7 & 12.0 & 11.7 & 11.5 & 11.5 & 11.5 & 11.3 & 11.1 \\ -5.2 & -4.8 & -6.4 & -0.3 & 3.1 & 3.0 & 1.2 & 0.5 & -0.3 & -0.9 & -1.6 \\ -5.9 & -6.5 & -6.8 & -1.1 & 1.9 & 3.5 & 1.2 & 0.4 & -0.4 & -1.0 & -1.6 \\ -1.8 & -3.7 & -4.5 & -0.7 & 2.1 & 3.0 & 2.4 & 1.7 & 1.1 & 0.7 & 0.3 \\ 25.6 & 27.8 & 31.1 & 26.3 & 25.5 & 25.4 & 25.6 & 25.9 & 25.9 & 25.9 & 25.9 \\ 23.8 & 24.1 & 26.6 & 25.6 & 27.6 & 28.4 & 28.0 & 27.6 & 27.0 & 26.6 & 26.2 \\ -3.4 & -1.6 & -2.6 & -0.8 & 0.8 & -0.6 & -1.2 & -1.3 & -1.5 & -1.7 & -1.8 \\ -2.3 & -0.6 & -3.1 & -0.5 & 0.1 & -0.6 & -1.2 & -1.3 & -1.5 & -1.7 & -1.8 \\ 2.3 & 0.9 & -0.4 & 1.7 & 1.8 & 1.7 & 1.1 & 1.2 & 1.2 & 1.1 & 1.1 \\ -4.6 & -1.5 & -2.7 & -2.2 & -1.7 & -2.2 & -2.3 & -2.5 & -2.7 & -2.8 & -2.9 \\ -1.1 & -1.0 & 0.5 & -0.3 & 0.7 & \ldots . & \ldots . & \ldots . & \ldots & \ldots & \ldots \\ -0.7 & -1.1 & 0.3 & 0.3 & -0.9 & 1.1 & 0.0 & 0.0 & 0.0 & 0.0 & 0.0 \\ -0.8 & -1.0 & 0.0 & 0.0 & 0.0 & 0.0 & 0.0 & 0.0 & 0.0 & 0.0 & 0.0 \\ 0.0 & 0.0 & 0.0 & 0.0 & 0.0 & 0.0 & 0.0 & 0.0 & 0.0 & 0.0 & 0.0 \\ 0.1 & -0.2 & 0.3 & 0.3 & -0.9 & 1.1 & 0.0 & 0.0 & 0.0 & 0.0 & 0.0 \\ 0.7 & 1.7 & 0.4 & 0.9 & 1.2 & -0.5 & 0.0 & 0.1 & 0.1 & 0.1 & 0.0 \\ & & & & & & & & & & \\ 232.2 & 196.3 & 155.0 & 182.2 & 200.3 & 212.9 & 216.3 & 215.8 & 214.7 & 210.8 & 205.0 \\ & & & & & & & & & & \\ 10.0 & 9.8 & 7.6 & 11.9 & 12.6 & 14.1 & 14.3 & 13.7 & 13.1 & 12.5 & 11.7 \\ 6.5 & 7.4 & 6.8 & 10.9 & 11.5 & 14.4 & 15.7 & 16.1 & 16.5 & 16.8 & 17.1 \\ & & & & & & & & \\ \ldots & \ldots . & \ldots . & \ldots . & \ldots . & 54.1 & 52.9 & 51.8 & 50.7 & 49.6 & 48.4 \\ \ldots & \ldots & \ldots & \ldots & \ldots & 54.1 & 55.9 & 57.7 & 59.2 & 60.4 & 61.4 \\ & & & & & & & & & & \\ & & & & & & & & & & \\ 7.8 & 2.7 & 5.6 & 4.9 & 3.7 & 4.6 & 4.6 & 4.9 & 5.2 & 5.5 & 5.9 \\ 5.5 & 5.6 & 5.4 & 5.2 & 5.0 & 5.0 & 5.0 & 5.0 & 5.0 & 5.0 & 4.9 \\ 3.9 & 1.7 & -0.4 & 3.9 & 4.0 & 3.5 & 2.3 & 2.4 & 2.4 & 2.4 & 2.3 \\ 9.4 & 9.6 & -4.8 & 3.0 & -5.9 & \ldots . & \ldots . & \ldots . & \ldots & \ldots & \ldots \\ 1.5 & 3.9 & 5.9 & 1.3 & 1.0 & 1.5 & 2.7 & 2.6 & 2.6 & 2.6 & 2.6 \\ 0.0 & 3.9 & 16.7 & 1.0 & 11.6 & 7.9 & 3.1 & 3.4 & 2.8 & 3.9 & 4.0 \\ -1.8 & -3.7 & -4.5 & -0.7 & 2.1 & 3.0 & 2.4 & 1.7 & 1.1 & 0.7 & 0.3\end{array}$

Growth of real primary spending (deflated by GDP deflator, in percent)

Primary deficit

ue and grants

Primary (noninterest) expenditure

Automatic debt dynamics $2 /$

Contribution from interest rate/growth differential 3/

Of which: contribution from real interest rate

Other identified debt-creating flows

Privatization receipts (negative)

Recognition of implicit or contingent liabilities

15 Other (specify, e.g. bank recapitalization)

16 Residual, including asset changes (2-3) 5 /

Public sector debt-to-revenue ratio $1 /$

Gross financing need 6/

In billions of U.S. dollars

Scenario with key variables at their historical averages $7 /$

Scenario with no policy change (constant primary balance) in 2011-2016

Key Macroeconomic and Fiscal Assumptions Underlying Baseline

Real GDP growth (in percent)

Average nominal interest rate on public debt (in percent) $8 /$

Average reappreciest rate (nominal rate minus change in GDP

percent)

1/ Indicate coverage of public sector, e.g., general government or nonfinancial public sector. Also whether net or gross debt is used.

2/ Derived as $[(r-p(1+g)-g+a e(1+r)] /(1+g+p+g p))$ times previous period debt ratio, with $r=$ interest rate; $p=$ growth rate of GDP deflator; $g=$ real GDP growth rate; $a=$ share of foreign-currency denominated debt; and $\mathrm{e}=$ nominal exchange rate depreciation (measured by increase in local currency value of U.S. dollar).

$3 /$ The real interest rate contribution is derived from the denominator in footnote $2 /$ as $r-\pi(1+g)$ and the real growth contribution as - 9

4/ The exchange rate contribution is derived from the numerator in footnote $2 /$ as ae(1+r).

6/ Defined as public sector deficit, plus amortization of medium and long-term public sector debt, plus short-term debt at end of previous perio

7/ The key variables include real GDP growth; real interest rate; and primary balance in percent of GDP. 


\section{Annex I. Transition of Fiscal Presentation to GFS2001}

Table A1 shows how the traditional presentation of central government translates into the GFS2001 conform presentation. There are several items in the traditional presentation that include sub-items that are allocated to separate lines in the GFS2001 presentation. This decomposition can only be done based on detailed information that is usually not available in the traditional presentation. Thus, the GFS2001 presentation for historical data-data before the submission of GFS2001 conform data started in 2006 - can only be approximated. The second column in Table A1 presents the classification adapted for the approximation. This approximation is also used to translate the budget 2011 into the GFS2001 conform presentation as the budget is presented in the traditional format. Tables A2 and A3 show the GFS2001 conform fiscal presentation for 2009 through 2016. 
Table A1. Transition of Traditional Presentation (first column) into GFS2001 Conform Presentation (first row)

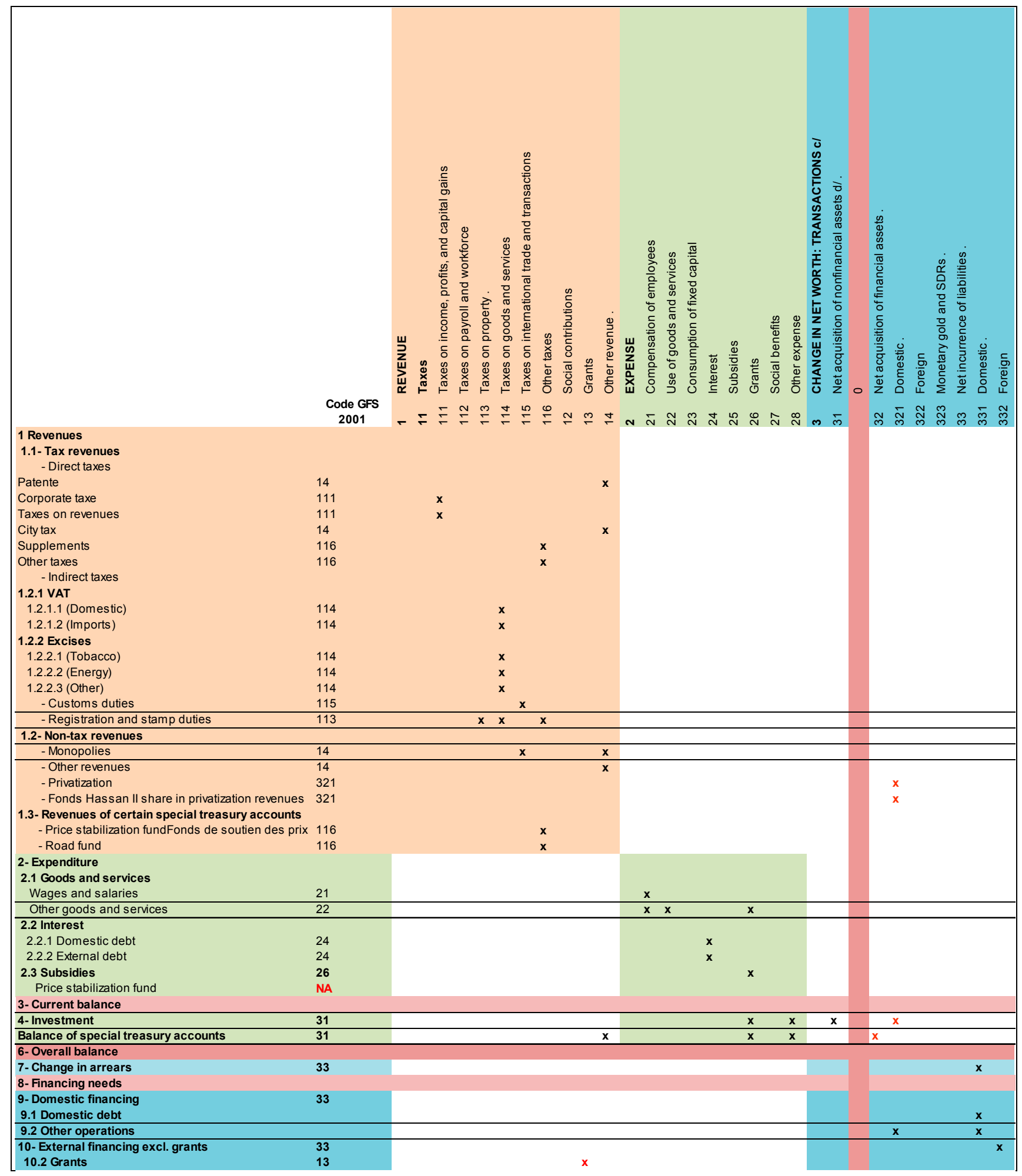




\begin{tabular}{|c|c|c|c|c|c|c|c|c|c|}
\hline \multicolumn{10}{|c|}{$\begin{array}{l}\text { Table A2. Morocco: Central Government Finance, 2009-11 } \\
\text { (In billions of dirhams) }\end{array}$} \\
\hline & 2009 & 2010 & LF 2011 1/ & 2011 & 2012 & 2013 & 2014 & 2015 & 2016 \\
\hline Revenue & 215,466 & 210,055 & 198,116 & 207,047 & 223,117 & 242,719 & 261,966 & 283,988 & 307,436 \\
\hline Taxes & 174,438 & 179,079 & 181,106 & 188,408 & 202,404 & 220,622 & 238,313 & 258,597 & 280,075 \\
\hline Taxes on income, profits, and capital gains & 69,821 & 62,702 & 66,035 & 67,205 & 72,635 & 78,152 & 84,362 & 91,728 & 99,742 \\
\hline Taxes on payroll and workforce & 0 & 0 & 0 & 0 & 0 & 0 & 0 & 0 & 0 \\
\hline Taxes on property . & 9,104 & 10,051 & 10,568 & 10,183 & 11,727 & 12,617 & 13,620 & 14,738 & 15,827 \\
\hline Taxes on goods and services & 74,708 & 87,169 & 87,772 & 91,845 & 100,418 & 111,812 & 120,696 & 130,883 & 142,624 \\
\hline Taxes on international trade and transactions & 14,785 & 13,606 & 11,225 & 12,040 & 11,709 & 11,826 & 12,766 & 13,814 & 13,808 \\
\hline Other taxes & 6,020 & 5,551 & 5,506 & 7,135 & 5,915 & 6,215 & 6,870 & 7,434 & 8,074 \\
\hline Social contributions & 0 & 0 & 0 & 0 & 0 & 0 & 0 & 0 & 0 \\
\hline Grants & 2,800 & 1,400 & 2,500 & 2,500 & 2,500 & 2,500 & 2,500 & 2,500 & 2,500 \\
\hline Other revenue. & 38,228 & 29,576 & 14,510 & 16,139 & 18,213 & 19,597 & 21,154 & 22,891 & 24,861 \\
\hline Expense & 196,601 & 211,519 & 185,033 & 211,796 & 220,290 & 233,821 & 246,437 & 262,034 & 278,466 \\
\hline Compensation of employees & 92,918 & 87,016 & 86,036 & 87,036 & 93,664 & 99,770 & 104,466 & 110,782 & 118,854 \\
\hline Use of goods and services & 26,315 & 25,817 & 42,953 & 37,953 & 45,069 & 48,492 & 52,345 & 57,523 & 62,115 \\
\hline Consumption of fixed capital (if available) & 0 & 0 & 0 & 0 & 0 & 0 & 0 & 0 & 0 \\
\hline Interest & 17,326 & 17,566 & 18,950 & 19,627 & 21,624 & 23,710 & 25,638 & 27,423 & 29,069 \\
\hline Subsidies & 0 & 0 & 0 & 0 & 0 & 0 & 0 & 0 & 0 \\
\hline Grants & 37,096 & 63,152 & 37,094 & 67,180 & 59,933 & 61,849 & 63,988 & 66,306 & 68,428 \\
\hline ow Fuel subsidies & 11,057 & 22,800 & 12,000 & 40,013 & 30,223 & 29,600 & 28,902 & 27,976 & 26,800 \\
\hline Food subsidies & 2,219 & 4,395 & 5,000 & 6,517 & 7,001 & 7,533 & 8,131 & 8,799 & 9,556 \\
\hline Social benefits & 0 & 0 & 0 & 0 & 0 & 0 & 0 & 0 & 0 \\
\hline Other expense & 22,946 & 17,968 & na & na & na & na & na & na & na \\
\hline Gross operating balance & 18,866 & $-1,464$ & 13,083 & $-4,749$ & 2,827 & 8,898 & 15,529 & 21,954 & 28,970 \\
\hline Net operating balance & 18,866 & $-1,464$ & 13,083 & $-4,749$ & 2,827 & 8,898 & 15,529 & 21,954 & 28,970 \\
\hline Net acquisition of nonfinancial assets & 32,028 & 32,232 & 44,097 & 39,097 & 46,299 & 49,623 & 54,174 & 58,622 & 62,712 \\
\hline Overall Deficit & $-13,162$ & $-33,696$ & $-31,014$ & $-43,846$ & $-43,471$ & $-40,725$ & $-38,645$ & $-36,668$ & $-33,742$ \\
\hline Overall deficit excluding grants & $-15,962$ & $-35,096$ & $-33,514$ & $-46,346$ & $-45,971$ & $-43,225$ & $-41,145$ & $-39,168$ & $-36,242$ \\
\hline Net lending / borrowing & $-13,162$ & $-33,696$ & $-31,014$ & $-43,846$ & $-43,471$ & $-40,725$ & $-38,645$ & $-36,668$ & $-33,742$ \\
\hline Net acquisition of financial assets & 2,290 & $-1,691$ & $-4,000$ & 0 & 0 & 0 & 0 & 0 & 0 \\
\hline Domestic . & 2,290 & $-1,691$ & $-4,000$ & 0 & 0 & 0 & 0 & 0 & 0 \\
\hline Foreign & 0 & 0 & 0 & 0 & 0 & 0 & 0 & 0 & 0 \\
\hline Monetary gold and SDRs. & 0 & 0 & 0 & 0 & 0 & 0 & 0 & 0 & 0 \\
\hline Net incurrence of liabilities. & 15,452 & 32,005 & 27,014 & 43,846 & 43,471 & 40,725 & 38,645 & 36,668 & 33,742 \\
\hline Domestic . & 5,430 & 17,497 & 19,977 & 36,809 & 38,123 & 33,901 & 31,575 & 29,077 & 26,052 \\
\hline Foreign & 10,022 & 14,508 & 7,037 & 7,037 & 5,348 & 6,824 & 7,070 & 7,591 & 7,690 \\
\hline \multicolumn{10}{|l|}{ Memo items: } \\
\hline Change in net worth: Transactions & 18,866 & $-1,464$ & 13,083 & $-4,749$ & 2,827 & 8,898 & 15,529 & 21,954 & 28,970 \\
\hline GDP & 732,449 & 767,096 & 814,608 & 814,608 & 875,123 & 941,595 & $1,016,404$ & $1,099,857$ & $1,194,510$ \\
\hline
\end{tabular}




\begin{tabular}{|c|c|c|c|c|c|c|c|c|c|}
\hline \multicolumn{10}{|c|}{$\begin{array}{l}\text { Table A3. Morocco: Central Government Finance, 2009-11 } \\
\text { (In percent of GDP) }\end{array}$} \\
\hline & 2009 & \multicolumn{2}{|c|}{2010 LF 2011 1/ } & 2011 & 2012 & 2013 & 2014 & 2015 & 2016 \\
\hline Revenue & 29.4 & 27.4 & 24.3 & 25.4 & 25.5 & 25.8 & 25.8 & 25.8 & 25.7 \\
\hline Taxes & 23.8 & 23.3 & 22.2 & 23.1 & 23.1 & 23.4 & 23.4 & 23.5 & 23.4 \\
\hline Taxes on income, profits, and capital gains & 9.5 & 8.2 & 8.1 & 8.3 & 8.3 & 8.3 & 8.3 & 8.3 & 8.4 \\
\hline Taxes on payroll and workforce & 0.0 & 0.0 & 0.0 & 0.0 & 0.0 & 0.0 & 0.0 & 0.0 & 0.0 \\
\hline Taxes on property. & 1.2 & 1.3 & 1.3 & 1.3 & 1.3 & 1.3 & 1.3 & 1.3 & 1.3 \\
\hline Taxes on goods and services & 10.2 & 11.4 & 10.8 & 11.3 & 11.5 & 11.9 & 11.9 & 11.9 & 11.9 \\
\hline Taxes on international trade and transactior & 2.0 & 1.8 & 1.4 & 1.5 & 1.3 & 1.3 & 1.3 & 1.3 & 1.2 \\
\hline Other taxes & 0.8 & 0.7 & 0.7 & 0.9 & 0.7 & 0.7 & 0.7 & 0.7 & 0.7 \\
\hline Social contributions & 0.0 & 0.0 & 0.0 & 0.0 & 0.0 & 0.0 & 0.0 & 0.0 & 0.0 \\
\hline Grants & 0.4 & 0.2 & 0.3 & 0.3 & 0.3 & 0.3 & 0.2 & 0.2 & 0.2 \\
\hline Other revenue & 5.2 & 3.9 & 1.8 & 2.0 & 2.1 & 2.1 & 2.1 & 2.1 & 2.1 \\
\hline Expense & 26.8 & 27.6 & 22.7 & 26.0 & 25.2 & 24.8 & 24.2 & 23.8 & 23.3 \\
\hline Compensation of employees & 12.7 & 11.3 & 10.6 & 10.7 & 10.7 & 10.6 & 10.3 & 10.1 & 10.0 \\
\hline Use of goods and services & 3.6 & 3.4 & 5.3 & 4.7 & 5.2 & 5.2 & 5.2 & 5.2 & 5.2 \\
\hline Consumption of fixed capital (if available) & 0.0 & 0.0 & 0.0 & 0.0 & 0.0 & 0.0 & 0.0 & 0.0 & 0.0 \\
\hline Interest & 2.4 & 2.3 & 2.3 & 2.4 & 2.5 & 2.5 & 2.5 & 2.5 & 2.4 \\
\hline Subsidies & 0.0 & 0.0 & 0.0 & 0.0 & 0.0 & 0.0 & 0.0 & 0.0 & 0.0 \\
\hline Grants & 5.1 & 8.2 & 4.6 & 8.2 & 6.8 & 6.6 & 6.3 & 6.0 & 5.7 \\
\hline ow Fuel subsidies & 1.5 & 3.0 & 1.5 & 4.9 & 3.5 & 3.1 & 2.8 & 2.5 & 2.2 \\
\hline Food subsidies & 0.3 & 0.6 & 0.6 & 0.8 & 0.8 & 0.8 & 0.8 & 0.8 & 0.8 \\
\hline Social benefits & 0.0 & 0.0 & 0.0 & 0.0 & 0.0 & 0.0 & 0.0 & 0.0 & 0.0 \\
\hline Other expense & 3.1 & 2.3 & na & na & na & na & na & na & na \\
\hline Gross operating balance & 2.6 & -0.2 & 1.6 & -0.6 & 0.3 & 0.9 & 1.5 & 2.0 & 2.4 \\
\hline Net operating balance & 2.6 & -0.2 & 1.6 & -0.6 & 0.3 & 0.9 & 1.5 & 2.0 & 2.4 \\
\hline Net acquisition of nonfinancial assets & 4.4 & 4.2 & 5.4 & 4.8 & 5.3 & 5.3 & 5.3 & 5.3 & 5.3 \\
\hline Overall Deficit & -1.8 & -4.4 & -3.8 & -5.4 & -5.0 & -4.3 & -3.8 & -3.3 & -2.8 \\
\hline Overall deficit excluding grants & -2.2 & -4.6 & -4.1 & -5.7 & -5.3 & -4.6 & -4.0 & -3.6 & -3.0 \\
\hline Net lending / borrowing & -1.8 & -4.4 & -3.8 & -5.4 & -5.0 & -4.3 & -3.8 & -3.3 & -2.8 \\
\hline Net acquisition of financial assets & 0.3 & -0.2 & -0.5 & 0.0 & 0.0 & 0.0 & 0.0 & 0.0 & 0.0 \\
\hline Domestic. & 0.3 & -0.2 & -0.5 & 0.0 & 0.0 & 0.0 & 0.0 & 0.0 & 0.0 \\
\hline Foreign & 0.0 & 0.0 & 0.0 & 0.0 & 0.0 & 0.0 & 0.0 & 0.0 & 0.0 \\
\hline Monetary gold and SDRs & 0.0 & 0.0 & 0.0 & 0.0 & 0.0 & 0.0 & 0.0 & 0.0 & 0.0 \\
\hline Net incurrence of liabilities. & 2.1 & 4.2 & 3.3 & 5.4 & 5.0 & 4.3 & 3.8 & 3.3 & 2.8 \\
\hline Domestic . & 0.7 & 2.3 & 2.5 & 4.5 & 4.4 & 3.6 & 3.1 & 2.6 & 2.2 \\
\hline Foreign & 1.4 & 1.9 & 0.9 & 0.9 & 0.6 & 0.7 & 0.7 & 0.7 & 0.6 \\
\hline \multicolumn{10}{|l|}{ Memo items: } \\
\hline Change in net worth: Transactions & 2.6 & -0.2 & 1.6 & -0.6 & 0.3 & 0.9 & 1.5 & 2.0 & 2.4 \\
\hline
\end{tabular}




\section{INTERNATIONAL MONETARY FUND}

\section{MOROCCO}

STAFF REPORT FOR THE 2011 ARTICLE IV

September 19, 2011

CONSULTATION-INFORMATIONAL ANNEX

Prepared By

The Middle East and Asia Department (in Consultation with Other Departments)

\section{CONTENTS}

RELATIONS WITH THE FUND

2

RELATIONS WITH THE WORLD BANK GROUP 4

STATISTICAL ISSUES 6 


\section{MOROCCO: RELATIONS WITH THE FUND}

(As of July 31, 2011)

\section{Membership Status \\ Joined: April 25, 1958; Article VIII}

\section{General Resources Account}

$\begin{array}{lrr} & \text { SDR Million } & \text { Percent Quota } \\ \text { Quota } & 588.20 & 100.00 \\ \text { Fund holdings of currency } & 517.76 & 88.02 \\ \text { Reserve position in Fund } & 70.45 & 11.98\end{array}$

\section{SDR Department}

$\begin{array}{lrr}\text { SDR } & \begin{array}{r}\text { Percent } \\ \text { Million }\end{array} & \begin{array}{l}\text { Allocation } \\ \text { Net cumulative }\end{array} \\ \text { allocation } & 561.42 & 100.00 \\ \text { Holdings } & 444.77 & 79.22\end{array}$

\section{Outstanding Purchases and Loans}

None

\section{Latest Financial Arrangements}

In millions of SDR, (mm/dd/yyyy)

$\begin{array}{cccrr}\text { Type } & \begin{array}{c}\text { Date of } \\ \text { arrangement }\end{array} & \begin{array}{c}\text { Expiration } \\ \text { Date }\end{array} & \begin{array}{r}\text { Amount } \\ \text { Approved }\end{array} & \begin{array}{r}\text { Amount } \\ \text { Drawn }\end{array} \\ \text { Stand-by } & 01 / 31 / 1992 & 03 / 31 / 1993 & 91.98 & 18.40 \\ \text { Stand-by } & \text { Jul. 20,1990 } & 03 / 31 / 1993 & 100.00 & 48.00 \\ \text { Stand-By } & \text { Aug. 30, 1988 } & 12 / 31 / 1989 & 210.00 & 210.00\end{array}$

\section{Projected Payments to Fund}

(SDR million; based on existing use of resources and present holdings of SDRs):

\begin{tabular}{l}
\multicolumn{4}{c}{ Forthcoming } \\
$\begin{array}{llll}\mathbf{2 0 1 1} & \mathbf{2 0 1 2} & \mathbf{2 0 1 3} & \mathbf{2 0 1 4} \\
& & & \\
0.31 & 0.68 & 0.68 & 0.68 \\
\mathbf{0 . 3 1} & \mathbf{0 . 6 8} & \mathbf{0 . 6 8} & \mathbf{0 . 6 8}\end{array}$
\end{tabular}

\section{Exchange Rate Arrangement and Exchange System}

Morocco maintains an exchange system that is free of restrictions on the making of payments and transfers on current international transactions. However, Morocco maintains certain restrictions relating to Iraq and the Federal Republic of Yugoslavia (Serbia and Montenegro), pursuant to UN Security Council Resolutions. These are subject to notification to the Fund in accordance with Decision 144 $(52 / 51)$. The exchange rate is freely determined in the interbank foreign exchange market, which was created in 1996. Bank Al-Maghrib (BAM) intervenes in the market to maintain the exchange rate within its target range, defined around a fixed central rate. Morocco has a conventional peg arrangement. The current exchange rate of the Moroccan dirham is pegged to a basket of currencies comprising the euro and the U.S. dollar, with respective weights of 80 and 20 percent. BAM fixes daily rates for the rated currencies on the basis of variations on the value of the basket. Rates for most currencies quoted in Morocco are established on the basis of the daily dirham-euro rate and the cross rates for those 
currencies in relation to the euro in the international exchange markets. As of August 15, 2011, the SDR/dirham exchange rate was SDR 1=MAD 12.58 .

\section{Article IV Consultation}

Morocco is on the 12-month cycle. The last discussions of the Article IV consultation were held in Rabat during November 2-13, 2009, and were concluded by the Executive Board on January 25, 2010.

\section{Technical Assistance}

2007-09: MCM-Peripatetic visitsAccounting, internal rating and bank supervision.

January 27-February 2, 2009: MCM-Stress

Testing and Macroprudential Analysis.
April 19-30, 2009: STA-National Accounts Statistics.

September 22-October 5, 2009: FAD—Recent Revenue Developments: Analysis and Implications to Fiscal Policy.

March 1-March 11, 2010: STA-Monetary and Financial Statistics.

February 9-February 18, 2011: MCM-Stress

Testing and Macroprudential Analysis.

March 30-April 12, 2011: STA-Monetary and Financial Statistics.

\section{Resident Representative}

None 


\title{
ANNEX II: MOROCCO-RELATIONS WITH THE WORLD BANK GROUP
}

\author{
JMAP Implementation, FY11
}

As of September 1, 2011

\begin{tabular}{|c|c|c|c|}
\hline Title & Products & $\begin{array}{c}\text { Provisional timing } \\
\text { of missions }\end{array}$ & $\begin{array}{c}\text { Expected } \\
\text { delivery date }\end{array}$ \\
\hline \multicolumn{4}{|c|}{ A. Mutual Information on Relevant Work Programs } \\
\hline $\begin{array}{l}\text { Bank work } \\
\text { program in } \\
\text { next } \\
12 \text { months }\end{array}$ & $\begin{array}{l}\text { a. } \\
\text { Trade \&evelopment Policy Lending on: } \\
\text { reform new series; Skills and Employment } \\
\text { I Financial Sector II; Education II (in } \\
\text { standby) } \\
\text { b. } \quad \text { Investment Lending : Judicial } \\
\text { Performance Enhancement; Ouarzazate } \\
\text { CSP; National Initiative for Human } \\
\text { Development II; } \\
\text { c. } \\
\text { - } \\
\text { - } \\
\text { Pector work on: } \\
\text { Poverty \& Labor market analysis } \\
\text { Public Expenditure Review (PER) } \\
\text { - } \\
\text { on health and education Justice } \\
\text { - } \\
\text { Cleand energy } \\
\text { Trade \& EU Integration } \\
\text { PETS in Health and Education } \\
\text { - } \\
\text { d. } \\
\text { Technical assistance on } \\
\text { Business Environment } \\
\text { Compensation reform } \\
\text { Macro-econometric modeling } \\
\text { Employment } \\
\text { Governance }\end{array}$ & $\begin{array}{l}\text { Ongoing activities } \\
\text { with multiple } \\
\text { missions throughout } \\
\text { the year }\end{array}$ & $\begin{array}{l}\text { All are FY11 } \\
\text { activities }\end{array}$ \\
\hline $\begin{array}{l}\text { IMF work } \\
\text { program in } \\
\text { next } \\
12 \text { months }\end{array}$ & $\begin{array}{l}\text { Staff visit } \\
\text { TA mission--STA: Monetary and Financial } \\
\text { Statistics }\end{array}$ & $\begin{array}{l}\text { End of } 2011 \\
03 / 1-03 / 11,2010\end{array}$ & \\
\hline
\end{tabular}




\begin{tabular}{|c|c|c|c|}
\hline & $\begin{array}{l}\text { Analytical work on unemployment } \\
\text { Preparing analytical work on investment } \\
\text { Preparing analytical work on labor market } \\
\text { mis-matches } \\
\text { Developing DSGE model } \\
\text { Multi-mission MCM TA project on macro- } \\
\text { prudential supervision and stress testing }\end{array}$ & $\begin{array}{l}\text { To be Presented in } \\
\text { Tunis } \\
\text { Ongoing } \\
\text { Ongoing } \\
\text { Ongoing } \\
\text { 10/05/11- } \\
10 / 10 / 2011\end{array}$ & \\
\hline \multicolumn{4}{|c|}{ B. Requests for Work Program Inputs } \\
\hline $\begin{array}{l}\text { Fund request } \\
\text { to Bank }\end{array}$ & $\begin{array}{l}\text { Developments on the subsidy reform } \\
\text { Sectoral analysis }\end{array}$ & $\begin{array}{l}\text { As needed } \\
\text { As needed }\end{array}$ & \\
\hline $\begin{array}{l}\text { Bank request } \\
\text { to Fund }\end{array}$ & $\begin{array}{l}\text { Assessment of macroeconomic stance and } \\
\text { prospects } \\
\text { Request for assessment letters to DPLs } \\
\text { Data sharing }\end{array}$ & $\begin{array}{l}\text { Semiannual (and on } \\
\text { ad hoc basis if } \\
\text { requested) } \\
\text { At least } 4 \text { operations } \\
\text { predicted } \\
\text { Ongoing }\end{array}$ & $\begin{array}{l}\text { Following } \\
\text { Article IV and } \\
\text { staff visits }\end{array}$ \\
\hline \multicolumn{4}{|c|}{ C. Agreement on Joint Products and Missions } \\
\hline $\begin{array}{l}\text { Joint products } \\
\text { in next } \\
12 \text { months }\end{array}$ & $\begin{array}{l}\text { Continuous close coordination on the } \\
\text { reform agenda }\end{array}$ & Ongoing & \\
\hline
\end{tabular}




\section{ANNEX III. MOROCCO-STATISTICAL ISSUES}

As of August 01, 2011

\section{Assessment of Data Adequacy for Surveillance}

General: Data provision is adequate to conduct effective surveillance.

National accounts: Real sector data are adequate for surveillance.

Government finance statistics: Fiscal data are adequate for surveillance.

Balance of payments statistics: External sector data are adequate for surveillance.

Monetary and financial statistics: They are adequate for surveillance.

II. Data Standards and Quality Morocco is a SDDS subscriber since December 2005. published in April 2003 (Country Report No. 03/92). 
Morocco-Table of Common Indicators Required for Surveillance (As of August 1, 2011)

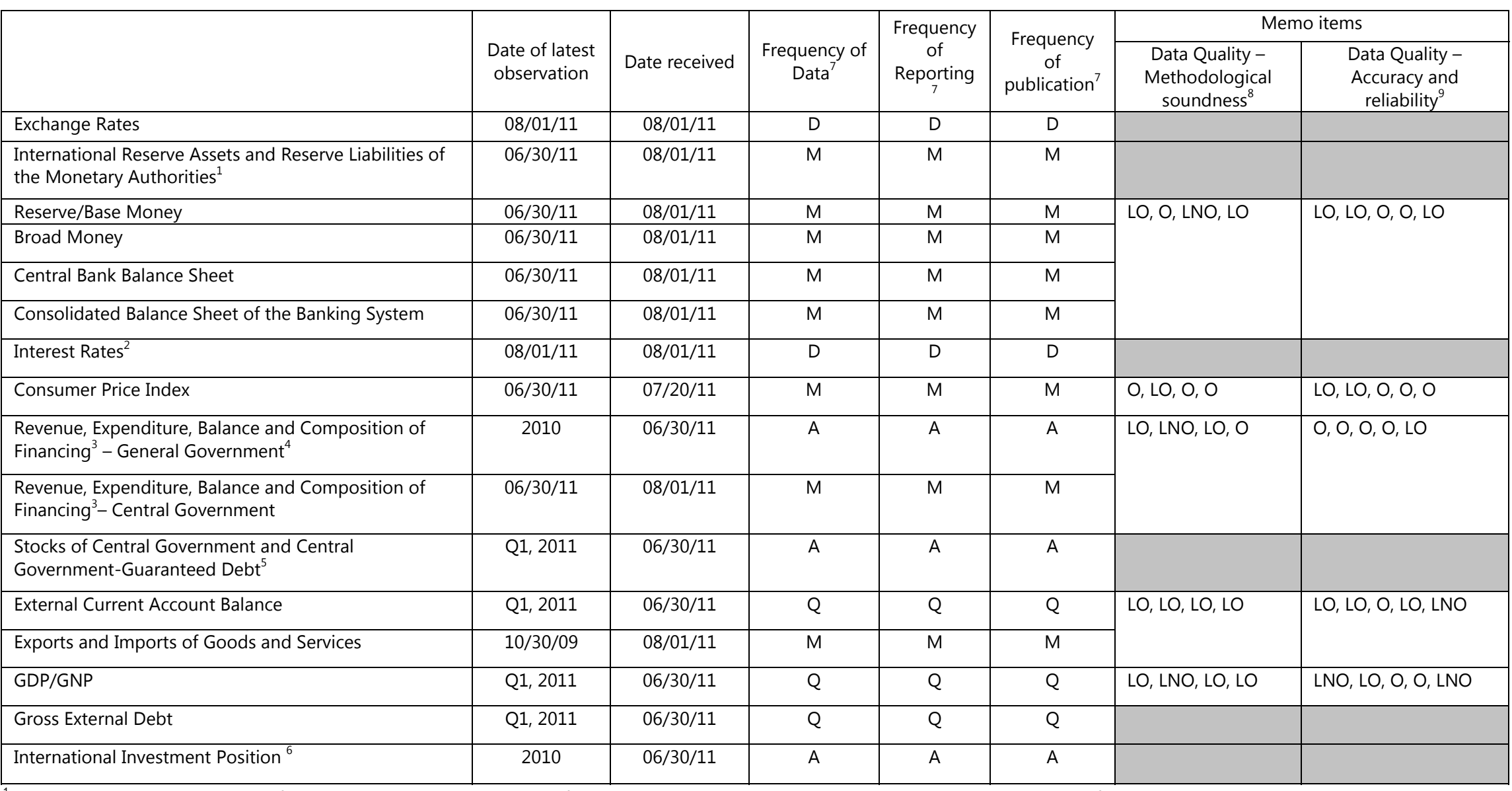

${ }^{1}$ Any reserve assets that are pledged of otherwise encumbered should be specified separately. Also, data should comprise short-term liabilities linked to a foreign currency but settled by other means as well as the notional values of financial derivatives to pay and to receive foreign currency, including those linked to a foreign currency but settled by other means.

${ }^{2}$ Both market-based and officially determined, including discount rates, money market rates, rates on treasury bills, notes and bonds.

${ }^{3}$ Foreign, domestic bank, and domestic nonbank financing.

${ }^{4}$ The general government consists of the central government (budgetary funds, extra budgetary funds, and social security funds) and state and local governments.

${ }^{5}$ Including currency and maturity composition.

${ }^{6}$ Includes external gross financial asset and liability positions vis-à-vis nonresidents.

${ }^{7}$ Daily (D), Weekly (W), Monthly (M), Quarterly (Q), Annually (A); Irregular (I); Not Available (NA).

${ }^{8}$ Reflects the assessment provided in the data ROSC published on April 4, 2003, and based on the findings of the mission that took place during January 16-30, 2002, for the dataset corresponding to the variable in each row. The assessment indicates whether international standards concerning concepts and definitions, scope, classification/sectorization, and basis for recording are fully observed (O), largely observed (LO), largely not observed (LNO), or not observed (NO).

${ }^{9}$ Same as Footnote 8, except referring to international standards concerning source data, statistical techniques, assessment and validation of source data, assessment and validation of intermediate data and statistical outputs, and revision studies. 


\section{INTERNATIONAL MONETARY FUND}

Public Information Notice

EXTERNAL

RELATIONS

DEPARTMENT
Public Information Notice (PIN) No. 11/133

FOR IMMEDIATE RELEASE

November 3, 2011
International Monetary Fund

$70019^{\text {th }}$ Street, NW

Washington, D. C. 20431 USA

\section{IMF Executive Board Concludes 2011 Article IV Consultation with Morocco}

On October 5, 2011, the Executive Board of the International Monetary Fund (IMF) concluded the Article IV consultation with Morocco. ${ }^{1}$

\section{Background}

Thanks to several years of sound macroeconomic policies and political reforms, Morocco was well equipped to address the 2008 international crisis and to respond to the social demands that have emerged during the Arab Spring. In this challenging environment, Morocco has performed well economically and has seen its social indicators improve.

Despite the slow recovery in the Euro zone-Morocco's main trading partner-overall GDP is expected to grow between $4 \frac{1}{2}-5$ percent, one of the highest in the region, reflecting sustained growth in the nonagricultural sector-including the tourism sector-and a rebound in agricultural output. Unemployment is stable at about 9 percent, but urban and youth unemployment remains high. In 2011, a fall in domestic food prices_resulting from the higher local supply of food-as well as the existing subsidies, which prevented inflationary pressures stemming from higher

\footnotetext{
${ }^{1}$ Under Article IV of the IMF's Articles of Agreement, the IMF holds bilateral discussions with members, usually every year. A staff team visits the country, collects economic and financial information, and discusses with officials the country's economic developments and policies. On return to headquarters, the staff prepares a report, which forms the basis for discussion by the Executive Board. At the conclusion of the discussion, the Managing Director, as Chairman of the Board, summarizes the views of Executive Directors, and this summary is transmitted to the country's authorities. An explanation of any qualifiers used in summings up can be found here: http://www.imf.org/external/np/sec/misc/qualifiers.htm.
} 
international prices, are expected to help limit the increase in the average inflation to around $1 \frac{1}{2}$ percent.

During the fiscal year 2011 and following domestic unrest, the authorities have increased public spending in some areas. Maintaining prices for certain food products and fuel unchanged in the context of rising international commodity prices, will require spending on food and fuel subsidies of about $51 / 2$ percent of GDP in 2011 , considerably in excess of the 2.1 percent of GDP estimated in the 2011 budget. In addition, all civil service wages were increased by a nominal amount of about US $\$ 75$, which is expected to increase the wage bill by 0.2 percent of GDP to 10.7 percent of GDP. At the same time, the authorities took significant offsetting measures, which will help containing the budget deficit at around 5.7 percent of GDP. The authorities are preparing to implement fiscal consolidation measures starting in 2012 to bring the deficit down to 3 percent of GDP in the medium term, which would bring the total public debt to about 50 percent of GDP in the medium term.

The external balance has slightly deteriorated due to a terms-of-trade shock. The current account deficit may increase to about 5 percent of GDP at end-2011. Although Moroccan exports, including phosphate and its derivatives, have performed well, and transfers from Moroccans living abroad and tourism receipts-despite the terroristic attack in Marrakesh on April 28-have grown, this may not completely offset the increase in imports caused by rising international food and oil prices. Gross international reserves are expected to decline slightly at end-2011, while remaining comfortable, at above 5 months of imports of goods and services.

Morocco's financial sector has made considerable headway, but it would need to mobilize additional resources to support financial development and adequate credit growth. The capital adequacy ratio of the system had risen to 12.3 percent at end-2010, up from 11.8 percent in 2009 , and NPLs steadily declined from 6.1 percent of total loans in 2008 to 4.8 percent in 2010. However, credit quality appears to have slipped since 2009 as indicated by the increase in the cost of risk in 2009-2010 and a slight increase in NPL ratio during the first five months of 2011. Efforts to strengthen core capital will continue.

The authorities are continuing their efforts to implement an ambitious program of structural reforms to enhance productivity. In this context, the authorities have set a committee to enhance the business environment to continuously attract FDI.

\section{Executive Board Assessment}

Executive Directors commended the authorities for their sound macroeconomic policies and structural and political reforms that have helped Morocco weather the global crisis and respond to pressing social needs. Looking ahead, Directors noted that significant challenges remain, including the uncertain economic outlook in Europe and the region, the need for fiscal 
consolidation in the face of large popular demands, and the urgency to implement an ambitious agenda to boost employment and inclusive growth. Rebuilding policy buffers and accelerating reforms are critical to strengthen the economy's resilience to shocks and lay a solid foundation for sustained growth over the medium term.

Directors stressed that containing and reorienting public expenditure, particularly by reforming the generalized subsidies system, will be key to ensuring medium-term fiscal sustainability. A well-targeted subsidy system would be less costly and better support the most needy segment of the population. Directors encouraged further efforts to strengthen revenue collection by broadening the tax base and improving tax administration, and commended the authorities for securing the mobilization of a greater share of domestic savings to provide additional resources to the financial sector.

Directors noted that moving to a flexible exchange rate would strengthen the central bank's monetary policy framework and enhance policy flexibility and together with structural reforms could help competitiveness going forward. They agreed with the authorities that the timing should be carefully considered and coordinated with other macroeconomic policies and necessary preparatory measures, so as to preserve medium-term fiscal sustainability and financial stability.

Directors stressed the critical importance of boosting growth to help reduce unemployment and improve living standards. They encouraged the authorities to press ahead with the ongoing and planned structural reforms, including by improving the efficiency and composition of public spending. Directors agreed that further efforts are required to improve governance, the business climate, and trade integration at the regional and global levels, and to strengthen human capital to increase private investment and continue to attract FDI. Further reforms to increase labor market flexibility and contain hiring costs also remain important to reduce youth unemployment.

Public Information Notices (PINs) form part of the IMF's efforts to promote transparency of the IMF's views and analysis of economic developments and policies. With the consent of the country (or countries) concerned, PINs are issued after Executive Board discussions of Article IV consultations with member countries, of its surveillance of developments at the regional level, of post-program monitoring, and of ex post assessments of member countries with longer-term program engagements. PINs are also issued after Executive Board discussions of general policy matters, unless otherwise decided by the Executive Board in a particular case. 
Morocco: Selected Economic Indicators, 2009-11

\begin{tabular}{|c|c|c|c|}
\hline & & Prel. & Staff Proj. \\
\hline & 2009 & 2010 & 2011 \\
\hline & \multicolumn{3}{|c|}{ (Annual percentage change) } \\
\hline \multicolumn{4}{|l|}{ Output and Prices } \\
\hline Real GDP (market price) & 4.8 & 3.7 & 4.6 \\
\hline Real nonagricultural GDP (market price) & 1.2 & 4.5 & 5.0 \\
\hline Consumer prices (end of period) & -1.6 & 2.2 & 2.0 \\
\hline Consumer prices (period average) & 0.9 & 1.0 & 1.5 \\
\hline & \multicolumn{3}{|c|}{ (In percent of GDP) } \\
\hline \multicolumn{4}{|l|}{ Investment and Saving } \\
\hline Gross capital formation & 35.6 & 35.1 & 35.0 \\
\hline Of which: Nongovernment & 31.9 & 32.0 & 31.8 \\
\hline Gross national savings & 30.2 & 30.8 & 29.8 \\
\hline Of which: Nongovernment & 25.1 & 27.5 & 28.1 \\
\hline \multicolumn{4}{|l|}{ Public Finances } \\
\hline Revenue 1/ & 27.2 & 25.1 & 25.6 \\
\hline Expenditure & 29.4 & 29.7 & 31.3 \\
\hline Budget balance & -2.2 & -4.6 & -5.7 \\
\hline Primary balance & 0.0 & -2.4 & -3.6 \\
\hline Total government debt & 47.9 & 51.1 & 54.2 \\
\hline & \multicolumn{3}{|c|}{$\begin{array}{l}\text { (Annual percentage change, unless } \\
\text { otherwise indicated) }\end{array}$} \\
\hline \multicolumn{4}{|l|}{ Monetary Sector } \\
\hline Credit to the private sector $2 /$ & 10.4 & 7.4 & 6.2 \\
\hline Broad money & 7.0 & 4.8 & 4.2 \\
\hline Velocity of broad money & 0.8 & 0.8 & 0.9 \\
\hline Three-month treasury bill rate (period average, in percent) & \multicolumn{3}{|c|}{$\begin{array}{c}3.3 \\
(\text { In percent of GDP, unless otherwise } \\
\text { indicated) }\end{array}$} \\
\hline \multicolumn{4}{|l|}{ External Sector } \\
\hline Exports of goods (in U.S. dollars, percentage change) & -30.2 & 25.3 & 25.6 \\
\hline Excl. phosphates and derivatives & -12.5 & 13.3 & 23.8 \\
\hline $\begin{array}{l}\text { Imports of goods (in U.S. dollars, percentage change) } \\
\text { Excl. energy }\end{array}$ & $\begin{array}{l}-23.4 \\
-21.6\end{array}$ & $\begin{array}{l}7.7 \\
4.5\end{array}$ & $\begin{array}{l}24.6 \\
21.4\end{array}$ \\
\hline Merchandise trade balance & -17.9 & -16.5 & -18.3 \\
\hline Current account excluding official transfers & -5.9 & -4.6 & -5.9 \\
\hline Current account including official transfers & -5.4 & -4.3 & -5.2 \\
\hline Foreign direct investment & 1.6 & 0.8 & 1.0 \\
\hline Total external debt & 23.3 & 24.6 & 24.8 \\
\hline Gross reserves (in billions of U.S. dollars) $3 /$ & 23.6 & 23.6 & 23.4 \\
\hline In months of next year imports of goods and services & 7.1 & 5.8 & 5.5 \\
\hline In percent of short-term external debt (on remaining maturity basis) & 1,793 & 1,538 & 1,521 \\
\hline \multicolumn{4}{|l|}{ Memorandum Items: } \\
\hline Nominal GDP (in billions of U.S. dollars) & 90.9 & 90.8 & 101.8 \\
\hline Unemployment rate (in percent) & 9.1 & 9.1 & $\ldots$ \\
\hline Net imports of energy products (in billions of U.S. dollars) & -6.7 & -8.1 & -11.0 \\
\hline Local currency per U.S. dollar (period average) & 8.1 & 8.4 & $\ldots$ \\
\hline $\begin{array}{l}\text { Real effective exchange rate (annual average, } \\
\text { percentage change) }\end{array}$ & 1.9 & -4.1 & $\ldots$ \\
\hline
\end{tabular}

Sources: Moroccan authorities; and Fund staff estimates.

$1 /$ Includes changes in the balance of other special treasury accounts.

$2 /$ includes credit to public enterprises.

$3 /$ As of 2009, reserves include the new SDR allocation. 


\section{Statement by Mohammed Daïri, Alternate Executive Director for Morocco October 5, 2011}

My authorities appreciate the hard work and dedication of staff and broadly concur with their analysis and conclusions in the concise and well-written report. After demonstrating strong resilience to the global financial crisis and the food and fuel price shock, Morocco is undergoing a major reform process to meet the expectations of its population toward more democracy and inclusiveness, increased employment opportunities, and improved social conditions. Early commitment of the highest authorities to political reform in response to the "Arab Spring" has paved the way for a peaceful and orderly transition to a constitutional and democratic monarchy. The new constitution approved on July 1 consecrates the rule of law, the principles of good governance, human rights protection and gender and regional equality, and strengthens the role and accountability of the executive branch, the responsibilities and oversight of parliament, as well as the independence of the judiciary.

The build-up of fiscal and foreign reserve buffers in the period preceding the global crisis provided the authorities with the policy space needed to support the economy and absorb the food and fuel price shock, and to make further progress in improving social indicators, including under the comprehensive National Initiative for Human Development. They were successful in striking the right balance between supporting economic activity, employment, and incomes, and maintaining macroeconomic and financial stability. Higher public investment in key infrastructure and social spending, moderate increases in wages and minimum pensions, and cuts in the high personal income tax rates consistent with the ongoing tax reform, in addition to the non pass-through of higher food and fuel prices, helped support domestic demand and growth. Monetary policy was also appropriately accommodative, providing the liquidity needed to meet private sector credit demand within a sound and effective regulatory and supervisory framework.

In a difficult external environment, Morocco's economic performance was broadly satisfactory. Growth averaged 41/2 percent during 2009-11, with nonagricultural GDP growing by $4 \frac{1}{2}$ percent in 2010 and 5 percent in 2011; inflation remained within the 1-11/2 range; and while declining somewhat, reserve coverage remained comfortable. More important, unemployment declined from 13.6 percent in 2000 to stabilize at around 9 percent during 2009-10, even though youth unemployment remained high. In view of the strength of Morocco's fundamentals and economic performance in a difficult external environment, its investment grade sovereign debt rating issued by Fitch in 2007 was confirmed by Standard \& Poor's in 2010.

The authorities are cognizant of the need to rebuild the fiscal buffers used since the onset of the global crisis. They have reiterated their commitment to resume fiscal consolidation by reducing the deficit to 3 percent of GDP and the debt-to-GDP ratio to less than 50 percent over the medium term, while increasing pro-growth, pro-poor spending, simplifying and 
modernizing the tax system, and further strengthening public financial management and the budgetary framework. To strengthen the foundations for sound policies, the new constitution requires both parliament and the government to safeguard fiscal balances, and the draft organic finance law being finalized introduces a medium term framework and results-based budgeting, as well as greater transparency and parliamentary involvement in the budget process. Also, as described in the staff report, the authorities have prepared a comprehensive reform of the compulsory public pension schemes to ensure their long term sustainability.

The authorities are firmly committed to reforming the subsidy system to achieve better targeting and rationalization and reduce the budgetary cost. Their decision to keep the prices of subsidized food and fuel products unchanged was motivated by their desire to mitigate the impact of price shocks on the poor, pending completion of the preparatory work and mobilization of the necessary consensus for moving to a better targeted system. To this end, and based on experiences from several countries and with World Bank assistance, they have started implementing pilot programs combining conditional cash transfers aimed at reducing school drop-outs (TAISSIR), which affects young girls in particular, and provision of free basic health to the poor (RAMED). These pilot programs were expanded under the 2011 budget and will be evaluated before their roll-out as part of the subsidy reform. However, the recent regional unrest made implementation of the reform politically difficult.

In an effort to limit the fiscal impact of increased spending on subsidies, the authorities reduced nonpriority recurrent spending in mid-2011 and limited transfers to public entities to what is needed for their investment program, while strengthening revenue collection. As a result, the deficit in 2011 is expected to increase by only 1.1 percent of GDP compared to 2010, despite an increase in subsidies by 2.2 percent of GDP. Over the medium term, their objective is to limit the cost of the subsidy system, including targeted social transfers, to 3 percent of GDP, down from 5.7 percent in 2011.

Bank Al-Maghrib (BAM) has been successful in maintaining very low inflation, helped by the decision to keep subsidized food and fuel prices unchanged, and the well- established credibility of monetary policy. The moderation of credit growth since 2010, after the rapid increase in previous years, does not seem to unduly constrain economic activity and has helped reduce risks from excessive credit expansion. Indeed, the slowdown mainly affected credit to real estate developers, whereas credit to investment and housing (in particular social housing) has remained in double-digits. The impact of the decline in foreign reserves on liquidity was offset by the provision of central bank liquidity, the lowering of reserve requirements, and diversification of bank resources through issuance of certificates of deposit. After increasing by 5.9 percent on a 12-month basis through May, credit to the private sector expanded by 7.1 percent through July and is expected to grow by more than 8 percent by end-2011. 
The authorities are comforted by the resilience of the financial sector, its increased soundness and profitability, as well as its regional expansion, with Moroccan banks now present in some 20 countries in Sub-Saharan and North Africa. NPLs have continued to decline, reaching 4.8 percent of total loans at end-2010, as against 15.7 percent in 2005 . Nevertheless, BAM remains vigilant to prevent the build-up of risks. It proactively raised capital requirements for all banks, instructed some banks to meet higher requirements as needed, and required constitution of provisions to mitigate the risks from large exposures, even though Morocco has the lowest large loan exposure along with the largest loan concentration in SMEs in the MENA region. ${ }^{1}$ Following the implementation of the standard approach under Basel II in 2007, BAM has issued regulations regarding the advanced approach, which is being implemented by the major banks, and is currently preparing banks for Basel III. It is also closely monitoring asset prices, which do not show signs of bubbles, and household indebtedness, which remains moderate.

The central bank law and the banking law are being revised to introduce a supervisory framework for systemic risks within a comprehensive approach to financial stability, including establishment of close coordination among interested parties. Activities of Moroccan bank subsidiaries are closely monitored, including through cooperation agreements with host country regulators. The authorities have also taken steps to enhance domestic savings mobilization, including a more favorable tax treatment of long-term savings and the expansion of the network and the range of services provided by the postal bank. The legal framework and governance structure for Casablanca Finance City has been adopted, together with a favorable tax treatment to promote it as an international and regional financial hub.

The authorities take note of staff assessment of the real exchange rate and their recommendation for greater exchange flexibility. The range of estimates for the REER and the analytical and data shortcomings involved are not conducive to firm conclusions. However, recent trends indicate some improvement in competitiveness, which has been confirmed by the relatively good performance of exports reflecting wage moderation and the success of various sectoral strategies developed in close cooperation with the private sector. Indeed, exports increased by 26 percent in 2010 and are projected to grow at a similar pace in 2011, with non-phosphate related exports growing by 23 percent. Tourism receipts and workers' remittances are projected to grow in 2011 by 13 percent and 11 percent respectively. This being said, although the authorities believe that improved competitiveness is better achieved through structural reforms, they reaffirm their readiness to move to a more flexible exchange rate system and to inflation targeting, once all necessary prerequisites are in place, including stronger foundations for medium-term fiscal sustainability.

\footnotetext{
${ }^{1}$ See Financial Access and Stability - A Road Map for the Middle East and North Africa, World Bank, 2011.
} 
Further improving the environment for private sector development continues to be central to the authorities' strategy of promoting employment and high and sustainable growth. In this regard, they attach high priority to human resource development to increase productivity and to support greater diversification toward higher value-added activities. In addition to the ongoing acceleration of infrastructure spending by the government, they intend to promote PPPs to diversify sources of financing and improve project selection and implementation through private sector participation. To improve transparency and good governance in this area and mitigate potential moral hazard, a regulatory framework in line with best international practices will be put in place. To reduce informality and level the playing field for businesses, a preferential tax treatment has been put in place for small businesses, which will bring them into the tax net while preserving their crucial role in production and employment. Concerns about the environment and energy security are being addressed through the development of renewable energy sources, including solar energy in which Morocco is playing a pioneer role through implementation of an ambitious program. Efforts continue to be made to improve governance and fight corruption, including through the establishment of an independent Council on Competition and a Central Authority for Corruption Prevention. The recently-announced advanced regionalization program, following a broad consultative process, should help achieve better integrated and more regionally balanced, sustainable, and equitable growth, while increasing ownership and accountability and improving efficiency of resource use.

The authorities agree on the importance of wage moderation and labor market flexibility for promoting employment and competitiveness. To this end, partners under the Social Dialogue agreed to a net income approach instead of focusing on nominal wage increases in their negotiations, and a large part of the improvement in employees' incomes in public and the private sectors in recent years reflected the decline in payroll taxes. Increases in minimum wages have been moderate in recent years, and a degree of flexibility has been introduced in their implementation, in particular for export-oriented sectors affected by the global crisis, which led to a decline in unit labor costs. It is expected that greater labor market flexibility will be introduced together with an unemployment protection system. Measures are also being taken to improve workers' social protection in line with international best practices which should result in improved productivity.

The authorities are committed to staying the course of prudent macroeconomic policy and structural reforms to promote employment and high and inclusive growth. They see the ongoing political reform as a golden opportunity to strengthen ownership of and support to sound economic and social policies. They are also firmly committed to strengthen regional cooperation, including within the Maghreb countries and with the Gulf Cooperation Council and other partners. 